\title{
EL ESPEJO DEFORMANTE. HERACLES EN EL CINE DEL SIGLO XXI
}

\author{
Joana Rodríguez Pérez \\ Universidad de La Laguna
}

\section{RESUMEN}

Este artículo analiza la manera en la que el cine del siglo Xxi acoge a una de las figuras más importantes de la mitología clásica, el héroe griego Heracles. De qué forma el arte cinematográfico ha captado y adaptado los hechos que las fuentes clásicas cuentan del mito del hijo de Zeus. Y más allá de su historia, de qué modo ha asumido, variado o descontextualizado la personalidad, los valores y la actitud de un ser muy de su tiempo. De esta manera, comparando la historia escrita con la historia rodada, examinamos qué episodios de la vida del héroe se han llevado a la gran pantalla, cuáles no y tratamos de explicar el porqué de ello. Esta comparativa, además, nos valdrá para determinar las interrelaciones que se producen entre la producción de los films y la obra literaria en la que estos se basan.

Palabras Clave: Heracles, cine, péplum, mitología, siglo Xxi, adaptación.

THE DISTORTING MIRROR.

HERACLES IN $21^{\text {ST }}$ CENTURY CINEMA

\section{Abstract}

This article examines how $21^{\text {st }}$-century cinema has embraced one of the most important figures in classical mythology, the Greek hero Herakles. How cinematic art has captured and adapted the events that classical sources tell of the myth of the son of Zeus. And beyond his story, how it has assumed, varied or decontextualized the personality, values and attitude of a being that was undeniably of his time. In this way, by comparing the written story with the filmed story, we examine which episodes of the hero's life have been brought to the big screen and which of them have not, and try to explain why. This comparison will also help us to determine the interrelations between the production of the films and the literary work on which they are based.

KeYwORDs: Heracles, cinema, peplum, mythology, $21^{\text {st }}$ century, film adaption. 


\section{LOS TEXTOS CLÁSICOS Y EL CINE}

En los primeros años del cine, los pioneros en este arte se valían de escenas costumbristas y prácticamente anecdóticas que llegaran más fácilmente a un público que estaba comenzando a asimilar un nuevo lenguaje. Además, la sencillez de los argumentos les permitía centrarse en la investigación, la innovación y el descubrimiento de las nuevas posibilidades de las que disponían y hasta dónde les permitía llegar el uso de la cámara. Con el paso del tiempo, fueron dándose cuenta de la capacidad narrativa que tiene el cine y a partir de entonces surge una fuerte relación entre este y la literatura que se mantiene vigente hasta hoy en día. La principal razón que tuvieron los cineastas para recurrir a la literatura fue el caudal de ideas y argumentos que esta proporcionaba, unida a que la mayor parte del público que acudía al cine ya conocía las obras y a sus autores, permitiendo así una mayor difusión y una mejor comprensión de los films a pesar de la ausencia de sonido en las primeras décadas.

La relación de las diferentes vertientes literarias con el nuevo arte ha sido siempre compleja y muy variada, y ha tenido un peso muy importante a lo largo de toda la historia del cine. Su reiterada utilización no disminuye la dificultad que comporta realizar una adaptación literaria pues, generalmente, la historia escrita ya tiene una importancia considerable por sí misma, y su lector, que antes daba, en cierto modo, rienda suelta a su imaginación, ahora recibe toda la información a través de las imágenes del film. A pesar de este riesgo, de lo que no cabe duda es de que "cuando se captan íntegramente representaciones teatrales extraordinarias, cuidadísimas en todos sus aspectos, de obras clásicas o de óperas, el cine asume un contenido cultural, de difusión muy eficaz» (Gómez Mesa, 1978).

En este sentido, dentro del gran abanico de fuentes que han servido a la inspiración cinematográfica, las obras de la literatura clásica griega-Homero, Eurípides, Apolodoro, etc.- han sido, desde el surgimiento del séptimo arte, uno de los temas más recurrentes para los cineastas. Y es que, ya desde la Antigüedad, la mitología ha sido una de las mayores productoras de espectaculares historias y hazañas que han inspirado a artistas de todos los tiempos. De este modo, con el paso de los años y la eclosión de nuevos métodos y lenguajes, la mitología continuará siendo una de las grandes inspiradoras para la producción artística incluyendo el campo cinematográfico. Así, desde fechas muy próximas a su aparición, los textos clásicos serán representados en la gran pantalla. Ya en 1898 -tres años después de la aparición oficial del cine- Georges Méliès rodaba Pygmalion et Galathée y un año más tarde, en 1899, Neptune et Amphitrite. Varios fueron los films que el francés dedicó a los temas mitológicos, pero no fue el único, se rodaron Venus et Adonis (1901), de Alice Guy; La naissance de Venus (1902), de Ferdinand Zecca; La caduta di Troia (1911), de Giovanni Pastrone; The Triumph of Venus (1918), de Edwin Bower Hesser; Helena (1924), de Manfred Noa; Night Life of the Gods (1935), de Lowell Sherman; o Mourning Becomes Electra (1947), de Dudley Nichols.

Siendo estos solo algunos de los títulos, ya que durante las primeras décadas del siglo $\mathrm{xx}$ fueron numerosas las producciones que partían de estos textos con, aproximadamente, tres mil años de antigüedad: 
A lo largo de las décadas de los 10, 20, 30 y 40 se continuó con la producción de films que trataban temas en esta misma línea, muchos basados en novelas históricas, aunque con algunas notables creaciones de origen mitológico, hasta llegar a la eclosión de los ańos 50, con algunas de las más importantes películas sobre la épica homérica, como las exitosas Ulises (Mario Camerini, 1954) o Helena de Troya (Robert Wise, 1955), y que propiciaron la aparición de un fenómeno de importancia en el ámbito cinematográfico, el péplum (Ramírez, 2017).

Es entonces, en los años 50, cuando estas películas cobran mayor importancia y dan lugar a la aparición de un género en sí mismo. Hay que tener en cuenta que el péplum, a lo largo de su desarrollo, se ha convertido en un género muy amplio y complejo que no se puede definir con unas características concretas y encorsetadas. Por tanto, dentro de este género, tal y como expone Antonio Gonzalès (1990), se pueden diferenciar cinco categorías diferentes:

- Le péplum à caractère mythologique comprenant les films sur Hercule et ses dérivés cinématographiques tels que Maciste, Ursus et les adaptations d'autres mythes tels que ceux d'CEdipe, d'Achille, etc. [...]

- Le péplum fantastique où l'on retrouve le film de S. Leone Le Colosse de Rhodes (1960) mais également des films alliant sans scrupules les différentes périodes historiques comme dans Toto contre Maciste (F. Cerchio, 1961) [...].

- Le péplum religieux qui est constitué de différents sous-groupes allant des adaptations bibliques telles que Les Dix Commandements de C.B. De Mille (1956) au martyre des chrétiens [...]. Il va sans dire que ce film spiritualiste nous semble appartenir au péplum par ses caractères chronologiques et par la thématique qui y est développée.

- Le péplum catastrophe a attiré lui aussi bon nombre de producteurs et de réalisateurs. Si l'intérêt fut grand, il se porta quasi exclusivement sur l'époque romaine qui offrait à la vision traditionnelle attachée à la Rome impériale des exemples symboliques [...].

- Le péplum militaire : certains lecteurs objecteront que le péplum possède comme une des caractéristiques fondamentales celle d'être un lieu où l'action se noue et se dénoue bien souvent autour d'une bataille ou d'un combat individuel de type héroïque ${ }^{1}$.

${ }^{1}$-El péplum de carácter mitológico incluye películas sobre Hércules y sus derivados cinematográficos como Maciste, Ursus y adaptaciones de otros mitos como los de Edipo, Aquiles, etc. [...]. - El péplum fantástico lo encontramos en la película de S. Leone El Coloso de Rodas (1960) pero también en películas que combinan sin escrúpulos los diferentes periodos históricos como Toto contra Maciste (F. Cerchio, 1961) [...]. -El péplum religioso se compone de diferentes subgrupos que van desde adaptaciones bíblicas como Los diez mandamientos (1956) de C.B. De Mille hasta el martirio de los cristianos [...]. Ni que decir tiene que estas películas espiritualistas parecen pertenecer al péplum por sus características cronológicas y no por el tema que en ellas se desarrolla. -El péplum de tragedia también atrajo a varios productores y directores. Si el interés era grande, este se centraba casi exclusivamente en la época romana, que ofrecía ejemplos simbólicos de la visión tradicional ligada a la Roma imperial [...]. -El péplum militar: algunos lectores objetarán que el péplum tiene como 
Así, dentro del péplum mitológico, además de las ya mencionadas por Ramírez Guedes, fueron producto de este periodo cumbre -décadas de los 50 y principios de los 60- films como L'amante di Paride (1954), de Marc Allégret, o La legenda di Enea (1962), de Giorgio Rivalta. Esta tendencia, aunque pierde fuerza después de estas fechas, no desaparece por completo, continuando su desarrollo a lo largo de la historia del cine y llevándonos hasta producciones realmente actuales ejecutadas ya en nuestro siglo. Así, en el siglo XXI, las producciones del péplum se distribuyen casi igualitariamente por los diferentes subgéneros. Sin embargo, el cambio es notorio dentro del péplum mitológico, que a diferencia de las producciones de los años 50 -que eran diversas y tomaban como inspiración muchas y variadas historias mitológicas- ahora habrá una tendencia clara hacia las historias de los principales héroes de los textos clásicos y sus sobrehumanas anécdotas. De esta manera la mayor parte de las producciones de péplum mitológico de los años 2000 tendrán como protagonistas, como ya se dijo, a dos de los héroes más conocidos de la mitología, ambos hijos de Zeus, Hércules y Perseo.

\section{HERACLES EN LA MITOLOGÍA GRECORROMANA}

La mitología está constituida principalmente por un conjunto de historias y leyendas relacionadas con la religión griega. Esta, en la actualidad, es entendida de manera general como el medio por el cual los antiguos griegos daban explicación a los sucesos de la naturaleza y a los diferentes acontecimientos que tenían lugar durante el desarrollo de su civilización. Era, en definitiva, parte de su conocimiento del mundo y el soporte cultural de su civilización.

Dentro de los cuantiosos textos que esta inspiró, son muchos los que recogen la historia de uno de los más importantes héroes de la mitología clásica griega, Heracles. La leyenda de este semidiós es una de las más extensas y complejas de los textos mitológicos, presentando diversas historias cumbres que se entrecruzan con otros muchos personajes y generan así distintas tramas dentro de una misma.

Heracles es hijo de Zeus y Alcmena, mortal de la que el dios se encaprichó y, tomando la forma de su esposo, el rey Anfitrión, yació con ella. A la vuelta del mortal, este se reconcilió con su esposa y engendraría a un segundo niño hermano gemelo de Heracles, Ificles. Celosa Hera de Alcmena y conocedora de que Heracles reinaría en Argos si naciera antes que su primo Euristeo, mandó a su hija Ilitía, diosa de los nacimientos, a retrasar el parto de Heracles e Ificles y a adelantar, por el contrario, el de Euristeo, quien heredaría finalmente el trono. Empujada por su inquina hacia Heracles, cuando era aún muy pequeño, Hera mandó dos grandes serpientes a su alcoba cuando este y su hermano descansaban en la cuna. Mientras

una de sus características fundamentales la de producirse en un lugar donde la acción se resuelve a menudo a través de una batalla o un combate heroico individual. Traducción de la autora. 
el pequeño Ificles rompió en llanto, su hermano cogió a los reptiles por el cuello -uno en cada mano- y los ahogó.

Ya en la etapa adulta, Hera continuó actuando en contra de Heracles y queriendo que se pusiera al servicio de su primo Euristeo mandó sobre él un arrebato de locura que le llevó a matar a su mujer, Mégara, y a sus hijos. Sintiendo la necesidad de expiar sus pecados, Heracles se postró ante Euristeo y aceptó realizar los doce trabajos que este le mandaría. Estas doce hazañas han sido las principales historias por las que se conoce a Heracles como uno de los más importantes héroes griegos, y que, por este orden, suponen:

1. Matar al león de Nemea y despojarle de su piel.

2. Matar a la hidra de Lerna.

3. Capturar a la cierva de Cerinea.

4. Capturar al jabalí de Erimanto.

5. Limpiar los establos de Augías.

6. Matar a las Aves del lago Estínfalo.

7. Capturar al toro de Creta.

8. Robar las yeguas de Diomedes.

9. Robar el cinturón de Hipólita.

10. Robar el ganado de Gerión.

11. Robar las manzanas doradas del jardín de las Hespérides.

12. Capturar al can Cerbero y sacarlo de los infiernos.

Además de estos, Heracles vivió otras hazañas independientes, paralelas o no a los doce trabajos, que también han fraguado su popularidad. Algunos ejemplos de ellas son:

- El enfrentamiento con Anteo: Anteo era hijo de Gea, la madre Tierra, y Posidón y vivía en Libia. Allí, hacía que cualquier extranjero que pasara por su tierra se enfrentara con él y una vez que le daba muerte, decoraba el templo consagrado a su padre con sus restos. Cuando Heracles iba en busca de las manzanas de oro (según Apolodoro, Biblioteca II, 11,23) o de las vacas de Gerión (según Diodoro Sículo, Biblioteca histórica Iv, 17, 4) pasó por la localidad y tuvo que enfrentarse al gigante, así, levantándolo de la tierra -de donde tomaba su fuerza-, Heracles le dio muerte.

[...] Heracles arribó a Libia. Lo primero que hizo fue retar a un combate a Anteo, de notoria fama por su fuerza física, su experiencia en la palestra y por dar muerte a todos los extranjeros que había vencido en la lucha; Heracles trabó combate con él y lo mató (Diodoro de Sicilia Iv, 17, 4).

Una vez informado atravesó Libia. Reinaba allí Anteo, hijo de Posidón, que daba muerte a los extranjeros obligándolos a luchar. Forzado a pelear con él, Heracles lo mató con su brazo mientras lo mantenía en vilo, pues si tocaba la tierra se vigorizaba, y por ello algunos dijeron que era hijo de Gea (Apolodoro II, 11, 23). 
- El enfrenamiento con Caco. Este episodio pertenece puramente a fuentes romanas como la Eneida de Virgilio (viII, 190-433) o Tito Livio (Historia de Roma desde su fundación, I, 1,7). Según estas, cuando Heracles regresó tras robar el ganado de Gerión, Caco hurtó al héroe algunos de los ejemplares que pastaban libres. Astuto, para no ser pillado por Heracles tiró de la cola de los animales para que estos caminaran hacia detrás y las huellas parecieran ir al sentido contrario al que realmente iban. Cuando Heracles finalmente se dio cuenta y lo descubrió lo mató con su maza. Además de las fuentes ya mencionadas, Ovidio recoge también el episodio en Fastos (I, 543-578):

... Era por la mańana; al despertar del sueńo, el Tirintio, que condujo el ganado, notó que le faltaban de la cuenta dos toros. [...] El feroz Caco los había arrastrado por el rabo a una cueva [...] Caco [...] de fuerzas proporcionadas a su talla, y su talla era enorme. Mulcíber ${ }^{2}$ era el padre de este fenómeno [...] el hijo de Júpiter se marchaba dando por perdida parte de sus bueyes; los animales robados mugieron con ronco bramido. «He oído el reclamo», dijo, y siguiendo el bramido llegó el vengador a la impía caverna [...] Caco emprendió el primer ataque a brazo partido, dirimiendo la cuestión salvajemente con piedras y estacas. Al no conseguir nada por estos medios, el muy cobarde acudió a las mañas de su padre, vomitando llamas por la boca que retumbaba [...] Consigue echarle mano el Alcida y sujetando la maza de tres nudos se la estampa al bandido tres o cuatro veces en plena cara. Este cae, vomitando humo mezclado con sangre, y al morir, golpea la tierra con su ancho pecho.

- Muerte de Licas. Licas fue el compañero de Heracles hasta su muerte. Tras servirle en la guerra contra Ecalia y vencer, el héroe heleno le mandó pedirle a Deyanira un atuendo apropiado para hacer el sacrificio a Zeus. La ninfa le entregó una túnica impregnada con la sangre envenenada de Neso que provocó en la piel de Heracles terribles heridas. Debido a su agonía en un acto desesperado el semidiós culpó a su compañero de lo ocurrido y agarrándolo por un pie lo lanzó al espacio. Según formula Apolodoro (II, 7, 7):

Con el fin de celebrar sacrificios envió al mensajero Licas a Traquis en busca de un hermoso vestido. Por él Deyanira supo de Yole y temerosa de que Heracles la prefiriese, creyendo que la sangre vertida por Neso era realmente un filtro amoroso, untó con él la túnica. Vestido con ella, Heracles se disponía a ofrecer el sacrificio, cuando, por calentarse la túnica, el veneno de la Hidra empezó a descomponer la piel; Heracles, cogiendo a Licas de los pies, lo despeñó y al intentar arrancarse la túnica, fuertemente adherida a su cuerpo, se desollaba.

2 Mulcíber es uno de los epítetos que se le atribuyen al dios romano Vulcano (equivalente de Hefestos en la mitología griega). 


\section{HERACLES COMO HÉROE CINEMATOGRÁFICO}

El cineasta italiano Giovanni Pastrone produjo en 1914 Cabiria, una película ambientada en la antigüedad e inspirada en las fuentes mitológicas, que contaba como protagonista con un personaje llamado Maciste, el cual originalmente respondía al nombre de Hércules ${ }^{3}$. Bajo estas características, este film puede considerarse el primero que trabaja en relación con la figura del héroe griego, aunque no sea de forma directa. A partir de esta cinta, el personaje de Maciste se convirtió en un protagonista frecuente en los films recreados en la antigüedad y, de algún modo, se le entendió como un sustitutivo -o un sinónimo- del verdadero Hércules. De este modo, en 1915, volvería a la pantalla con Maciste, de Giovanni Pastrone y Vincenzo Denizot (Giordano, 1998).

Sin embargo, aunque estos films pueden entenderse como el inicio de la «carrera cinematográfica» del héroe, su debut tuvo lugar en 1958 con el film de Pietro Francisci Le fatiche di Ercole (Hércules), protagonizada por Steve Reeves, y su secuela al año siguiente, Ercole e la regina di Lidia (Hércules y la Reina de Lidia).

Con el auge del péplum italiano serán cuantiosos los films que, a pesar de no contar con absoluto rigor histórico, retroceden al tiempo de las antiguas Grecia y Roma. Además, cientos de ellas, producidas a lo largo de todo el siglo xx, tendrán como protagonista al hijo de Zeus y Alcmena pero no por ello se desarrollan exclusivamente en el tiempo que se supone que el héroe vivió. De este modo, Hercules in New York (Hércules en Nueva York), de 1969, protagonizada por Arnold Schwarzenegger ${ }^{4}$, es ejemplo del impulso que tuvo la figura del héroe mitológico en el cine y cómo este la usó sin el más mínimo escrúpulo. En 1997, incluso Disney estrena una versión de animación del personaje absolutamente descontextualizado donde se nos presenta a un Hércules Olímpico enfrentado a Hades.

Desde entonces, Heracles desapareció de las pantallas y no regresó a ella hasta siete años más tarde, en el 2005, con Hercules, de Roger Young. Sin embargo, aunque este fue el primer contacto cinematográfico del último milenio, su figura reaparecería con mucha más fuerza en el 2014. Así, en este año se estrenaron tres películas que llevan en el título el nombre del héroe: Hercules Reborn, The legend of Hercules y Hercules. Estas últimas cuatro producciones, que tienen lugar en este siglo, son por tanto, el objeto de nuestro estudio.

${ }_{3}^{3}$ Macistius, en su forma latina, también era un epíteto de Heracles mencionado por Estrabón: «A medio camino del templo de Heracles Macistio y el río Acidón» (Estrabón viII, 3, 21).

${ }^{4}$ Arnold DStrong en los títulos de crédito. 

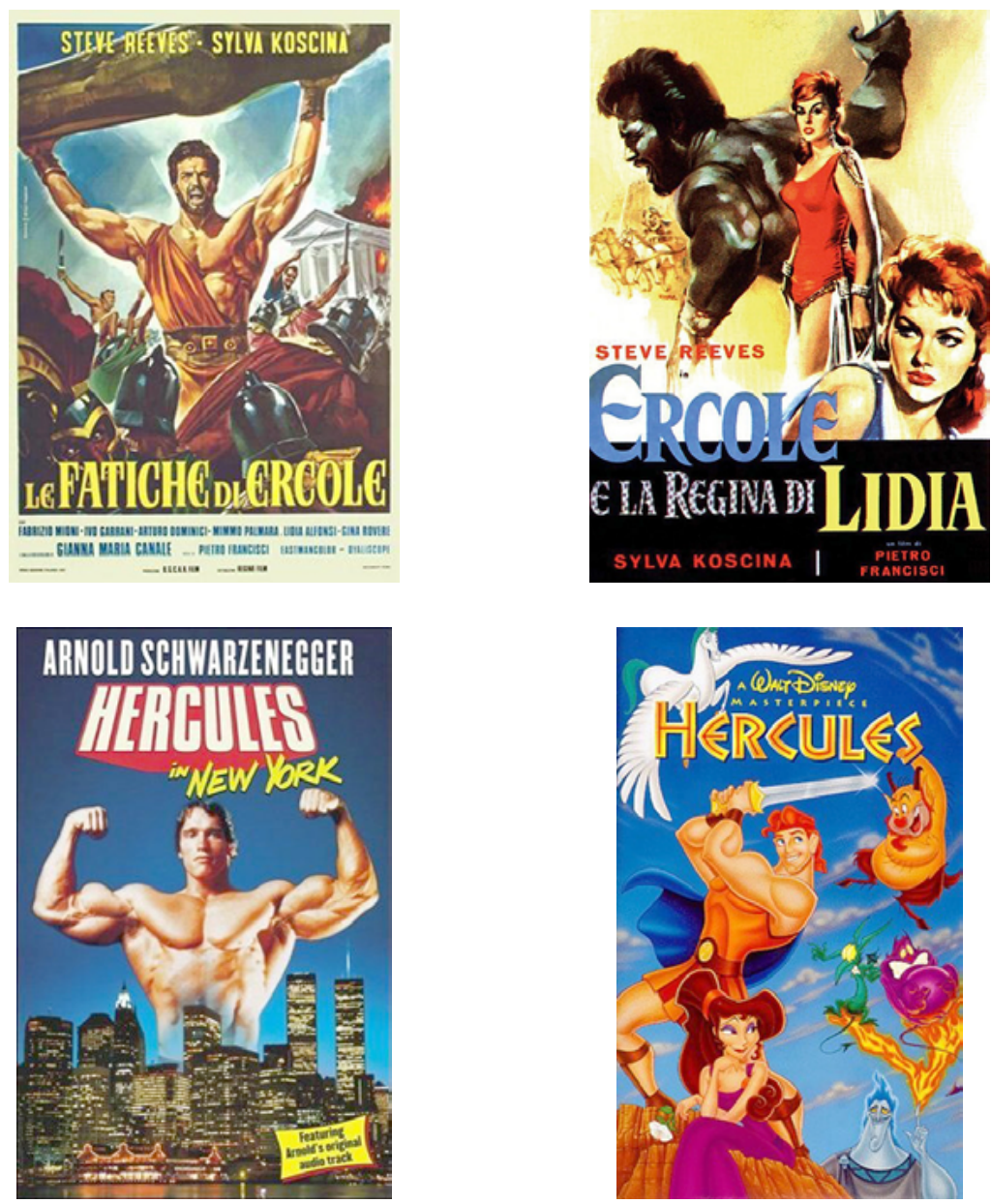

\section{HERCULES (2005), ROGER YOUNG}

Este film, producido a partir de una miniserie de televisión, se abre al espectador con la escena de un festejo consagrado a la diosa Hera en el que sus devotas hacen un sacrificio en su honor. En esta ocasión las mujeres descubren que su ofrenda es un hermafrodita y que por pertenecer mitad de su ser al mundo femenino, no pueden matarlo. Es por ello que Alcmena -la sacerdotisa- le hiere en los ojos dejándole ciego.

Esa misma noche, Alcmena yace con un hombre al que no se le ve el rostro pero muestra en el brazo una cicatriz en forma de rayo que parece hacer alusión a Zeus, ya que el rayo es su atributo. Sin embargo, vista esta escena por Linus, esta marca hará que más tarde el misterioso personaje sea identificado por este de manera que, al final del film, se nos desvela que realmente el hombre que fuerza a 
Alcmena no era Zeus sino Anteo ${ }^{5}$, lo cual supone una importante deformación del mito de Heracles.

$\mathrm{Al}$ amanecer, Tiresias ${ }^{6}$, vidente al que Alcmena había dejado ciego la noche anterior, comparece ante el matrimonio y advierte que la mujer está embarazada de dos hijos y uno de ellos no es de Anfitrión. La obsesión que presentan los personajes de esta película por la rivalidad entre Hera y Zeus hace que Alcmena rechace por completo al que cree hijo de Zeus y quiera incluso deshacerse de él incrementando su odio cuando Tiresias advierte que «el siguiente hijo nacido de la casa de Perseo ascenderá al trono de Tirinto y regirá todas las tierras que tú riges ahora». Finalmente, Alcmena alumbra a sus dos hijos (fig. 1), pero antes había llegado al mundo el hijo varón de Esténelo ${ }^{7}$-tío de Alcmena y rey de Tirinto-, Euristeo, quien heredará el trono.

Esta escena de la concepción y alumbramiento del héroe y su hermano está recogida por varios mitógrafos. Apolodoro en Biblioteca (II, 4, 8) menciona el episodio contando que antes de que Anfitrión llegara a Tebas, Zeus se transformó en él y yació con Alcmena una noche que hizo durar 24 horas. Cuando el rey llegó y vio que Alcmena le recibía con desgana le preguntó por qué lo hacía y esta respondió que ya había estado con él la noche anterior, más tarde Tiresias aclaró a Anfitrión que la unión amorosa había sido con Zeus. Finalmente Alcmena concibió dos hijos, uno de Zeus (Heracles) y otro de Anfitrión (Ificles). Por su parte, Higino, en las Fabulas (xxix), lo expone prácticamente de la misma forma, pero obviando la existencia de un segundo hijo engendrado por Anfitrión.

La mayor de las distorsiones que comete el film en este episodio es sin duda la aparición de la figura de Anteo, que además de no tener lugar en el mito, no se encuentra justificación posible para adjudicarle en el film la paternidad de Hércu-

5 A pesar de que en esta película toma un lugar que en los textos no corresponde, cabe aclarar que Anteo, como ya vimos más arriba, fue un personaje mitológico hijo de la madre Tierra y que, como en el film, ganaba su fuerza de ella. Además, también es cierto que luchó contra Heracles y este lo mató. Sin embargo, a diferencia de la película, el hecho ocurrió mientras Heracles pasaba por Libia de camino a buscar las manzanas de oro y lo mató ahogado entre sus brazos. Así lo cuenta Apolodoro (II, 5, 11).

${ }^{6}$ Tiresias en la mitología es un célebre adivino. Hay varias versiones de cómo consiguió su don. Apolodoro (III, 6, 7) lo expone de la siguiente forma «... Unos dicen que lo cegaron los dioses por haber revelado a los hombres sus secretos; pero según Ferecides lo cegó Atenea, pues [...] él vio a la diosa completamente desnuda y esta, tapándole los ojos con sus manos, lo cegó...». Por su parte Hesíodo en Fragmentos apunta que Tiresias «había hallado unas serpientes copulando cerca de Cilene y, por haberlas herido, fue transformado de hombre en mujer; pero al ver aquellas serpientes uniéndose en otra ocasión, se volvió hombre de nuevo, por eso cuando Zeus y Hera disputaban sobre quién disfrutaba más en el amor [...] preguntaron a Tiresias. Este dijo que, si el placer tuviera diez partes, los hombres gozarían sólo de una y las mujeres de nueve; entonces Hera lo cegó, pero Zeus le concedió el arte de la adivinación». Con esto también se explica el porqué de que en el film lo presentaran como un hermafrodita (Melampodia, 275).

7 Según las fuentes (Apolodoro II, 4, 5), Esténelo es hijo de Perseo y Andrómeda y padre, junto con Nicipe, de Euristeo. Además, tío de Alcmena. De esta manera el personaje coincide perfectamente en el film y en las fuentes clásicas. 
les y que posteriormente Alcmena obvie este hecho culpando a Zeus de una actitud lujuriosa.

De nuevo en el film, cegada de rabia y con el objetivo de deshacerse del hijo de Zeus, Alcmena acude a las "Favoritas de Hera», dos harpías ${ }^{8}$ que, para identificar cuál de los dos niños es hijo del dios, hacen que los pequeños mamen de su pecho alegando que solo un verdadero hijo engendrado por Zeus podría alimentarse de ella. Sin embargo, el pequeño que se amamanta primero (fig. 2), no solo coge el pecho, sino que se aferra con ganas a él y lo muerde sin soltarlo'. De esta manera, las harpías identifican al hijo de Zeus y le dan el nombre de Hércules - Heracles significa la "gloria de Hera»- mientras que, por su parte, Alcmena llama a su otro hijo Ificles.

Tras la visita a las harpías, afanada por matar a Hércules, Alcmena pide a Anfitrión que se deshaga del niño, pero como este se niega a hacerlo, la mujer coloca dos serpientes en la cuna del Hércules aún bebé (fig. 3), pero el pequeño, en lugar de asustarse, las agarra con las manos y las mata (fig. 4).

En los textos clásicos, este suceso tiene diferentes versiones. Primero se debe aclarar que las harpías no tienen nada que ver con la leyenda de Heracles. Además de esto, el nombre del héroe fue acuñado, según Apolodoro (II, 4, 12), por la Pitia ${ }^{10}$ cuando ya este entraba en la edad adulta. Del mismo modo, es erróneo atribuir a estos seres el amamantamiento del muchacho ya que en los textos quien le amamanta es la propia Hera. Sin embargo, es lógico que en el film se les atribuya a ellas ya que a pesar de que los dioses son nombrados constantemente, nunca se les muestra, de modo que Hera no podría aparecer. Es también responsabilidad de la diosa el suceso de las serpientes, pues tal y como Píndaro (Nemea I, 35) expone estando Heracles recién nacido Hera envió unas serpientes que penetraron en la habitación para acabar con los niños. Pero Heracles las sujetó con sus dos manos por sus cuellos durante tanto tiempo que las dejó sin aliento. Sin embargo, según cuenta Apolodoro en Biblioteca II, 4, 8, otros mitógrafos como Ferecides afirman que fue el propio Anfitrión quien expondría a los pequeños ante los reptiles para saber cuál de ellos era el hijo de Zeus y cuál suyo. Teniendo en cuenta que el personaje de Alcmena representa a una sacerdotisa de Hera -siendo en cierto sentido representación de ella- y que desde el primer momento muestra una actitud de rechazo hacia su propio hijo, es completamente lógico dentro del guion y de la trama que sea ella

${ }^{8}$ Las harpías son seres alados que pertenecen a la generación preolímpica, hijas de Electra y Taumante. Suelen ser dos: Aelo (también Nicótoe) y Acípete, aunque se conoce también una tercera: Celeno. Su iconografía responde a mujeres aladas o aves con cabeza de mujer y afiladas garras. Son raptoras de niños y de almas.

9 Esta escena de la película se puede relacionar con la leyenda del surgimiento de la Vía Láctea, ya que no deja de ser una variación de este suceso. Según las fuentes, cuando Heracles era aún un niño se amamantó del seno de Hera para conseguir la inmortalidad. Se cuenta que fue Hermes quien le acercó al pecho de la diosa mientras esta dormía, y que cuando se despertó lo apartó de ella bruscamente. Así, la leche que se derramó dejó una marca en el cielo: la Vía Láctea.

${ }^{10}$ La Pitia era la sacerdotisa mayor del templo de Apolo en Delfos y la que daba respuestas a las consultas del oráculo. Su nombre viene de «Pito», que es el nombre original del lugar donde se emplazó el santuario. 


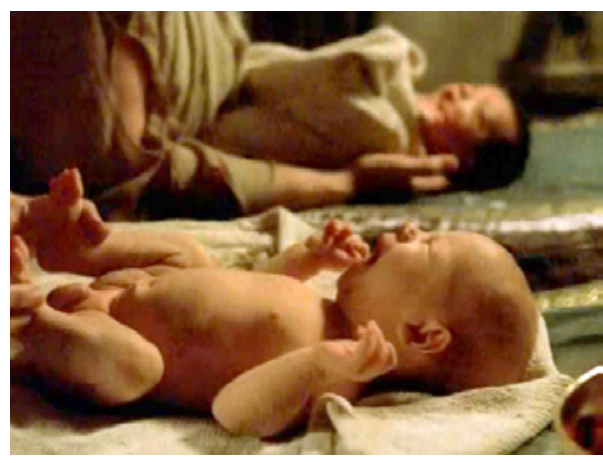

Fig. 1. Hércules e Ificles recién nacidos.

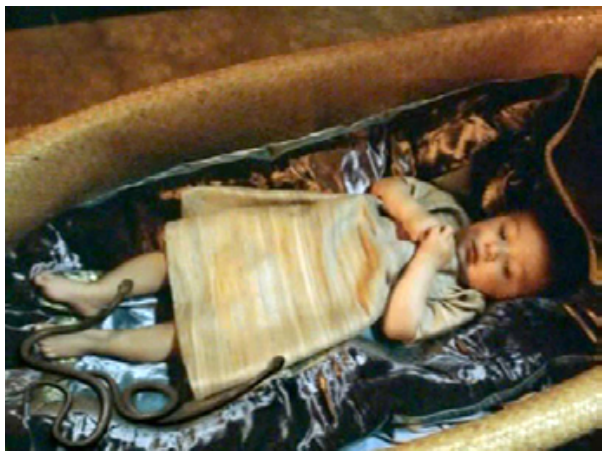

Fig. 3. Las serpientes que Alcmena deposita en la cuna amenazan al pequeño Hércules.

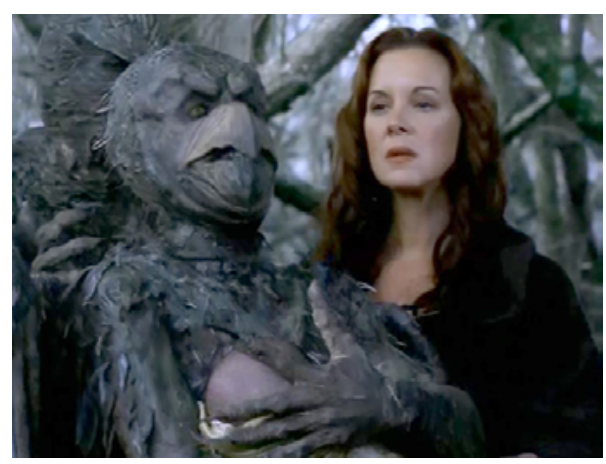

Fig. 2. Hércules amamantándose de la harpía mientras Alcmena espera para saber cuál de sus hijos es de Zeus.

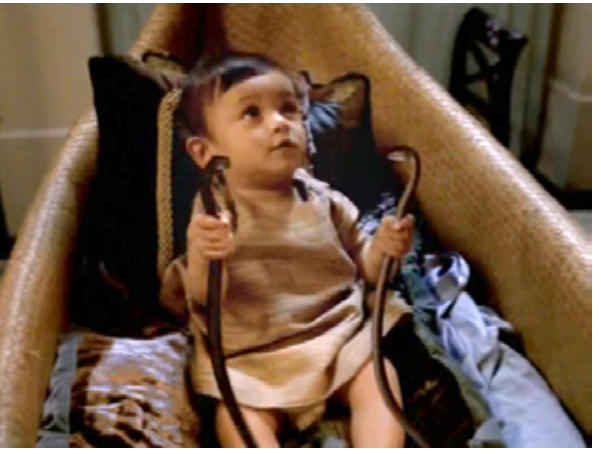

Fig. 4. Hércules ahoga a los dos reptiles.

quien intente matar a Hércules con las serpientes y no Hera, que como decíamos nunca aparece de forma física, o Anfitrión, que ha sido de algún modo su protector. En esta producción de 2005, la formación del joven Hércules es simultánea con la de su hermano Ificles y está bajo la responsabilidad del centauro Quirón ${ }^{11}$, quien los instruye en el arte de manejar la espada, y Linus quien los ilustra en el arte de la música. Hércules, si destacaba en las lecciones del centauro, no gozaba

${ }^{11}$ Según la mitología, Quirón es el más célebre y sabio de los centauros. Además de a Heracles, también educó a Aquiles, Jasón, Asclepio y, según algunos, hasta al propio Apolo. Sus lecciones incluyen la música, el arte de la guerra, la caza, la medicina y la moral. 


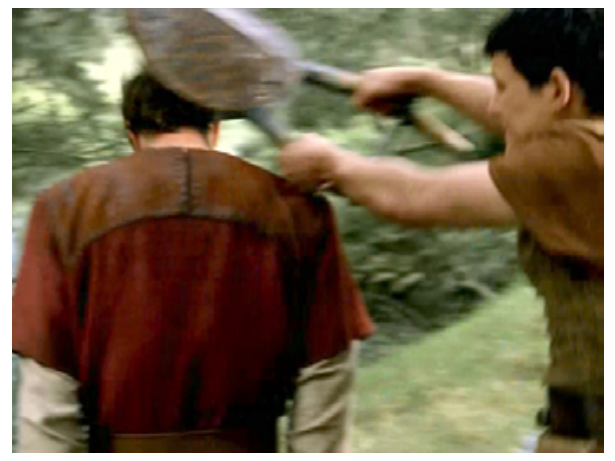

Fig. 5. Hércules golpeando a Linus con la lira. Hércules (2005), Roger Young.

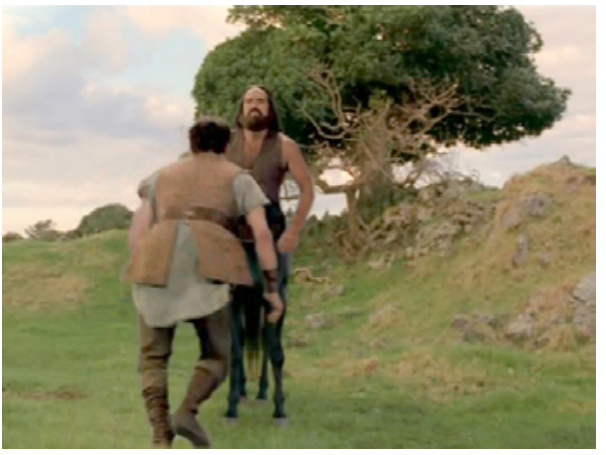

Fig. 7. Quirón y Hércules en las montañas. Hércules (2005), Roger Young.

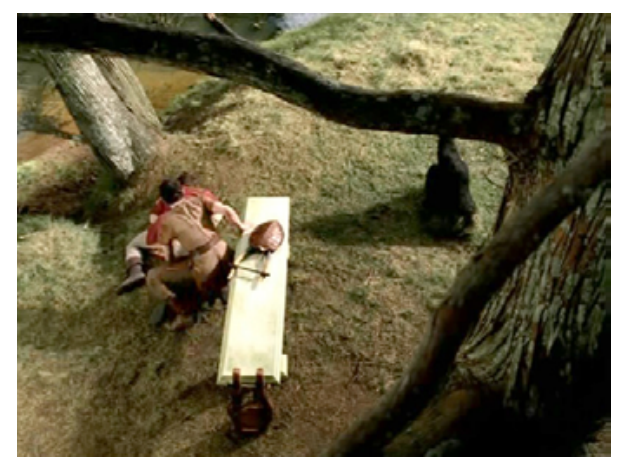

Fig. 6. Linus desfallecido tras recibir un golpe en la cabeza por parte de Hércules. Hércules (2005), Roger Young.

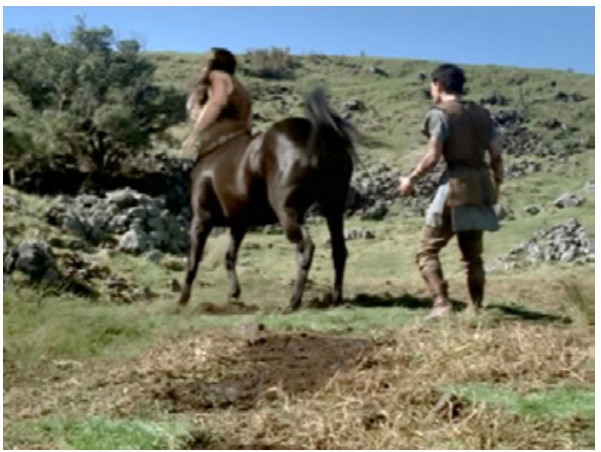

Fig. 8. Quirón y Hércules en las montañas. Hércules (2005), Roger Young.

de la misma suerte en la música, así que irritado por las reprimendas y golpes que el maestro le daba alzó el instrumento que estaba tocando y golpeó al músico en la cabeza dejándole inconsciente en el suelo (figs. 5 y 6). Creyendo que Hércules había causado la muerte de Linus -en realidad será salvado por la ninfa Deyanira-, el rechazo hacia el muchacho en la ciudad de Tebas fue en aumento y el rey Creón ${ }^{12}$ -padre de Mégara, muchacha por la que Hércules mostraba interés- le perdona la vida, pero con la condición de que abandone la ciudad yéndose a las montańas a cuidar del ganado de su padre. De esta manera, el joven se marcha con Quirón, quien le formará y cuidará lejos de su familia (figs. 7 y 8 ).

12 En la mitología su nombre es Creonte y ciertamente fue rey de Tebas y padre de Mégara. 
Sin embargo, la formación y juventud del héroe tebano cuentan los textos que corrió a cargo de diferentes personas. Apolodoro (II, 4, 9) nos dice que Heracles fue instruido por Anfitrión a manejar el carro, por Autólico a luchar, por Éurito a disparar el arco, por Cástor a usar las armas y por Lino a tocar la cítara. Este último será el personaje al que el film es fiel, a excepción de modificar su nombre por una versión latina -Lino equivale a Linus- y de «resucitarlo» convirtiéndolo más tarde en el fiel amigo de Hércules. En este aspecto las fuentes son rotundas y describen el asesinato del músico por parte de Hércules con un golpe en la cabeza con una lira o una cítara, pero a diferencia de la película, en la mitología fue el propio Anfitrión quien, por miedo a que cometiera otro delito, envió al joven fuera de la ciudad a cuidar el rebaño, donde llegó a la adultez consiguiendo gran altura y fuerza. De lo que no hay constancia en el mito es de la presencia del centauro Quirón.

De esta primera parte del film, en la que se presenta la concepción, el nacimiento y la juventud del héroe, se puede decir que, aunque es evidente que añade modificaciones con respecto a los textos, se muestra de forma bastante fiel la realidad del inicio de vida de Heracles. Así, la película permite que el espectador -aun pudiendo ser ignorante de los mitos- recree en su mente una idea bastante próxima a las fuentes clásicas. Esta producción, ya sea por su minutaje o por su interés en aproximarse a los textos originales a diferencia de la mayoría de las películas que tratan la vida del héroe griego, es la que mejor expone esta etapa de su vida. De manera general, los films se centran en la vida gloriosa de Hércules y, además de su enfrentamiento con las serpientes, que es considerada su primera gran hazaña, no suelen detenerse en otros hechos de su infancia. Por el contrario, la película de Young hace un recorrido bastante próximo a su juventud acercándonos incluso a qué tipo de formación recibió el héroe.

A pesar de que esta producción le preste especial interés al crecimiento del joven Hércules, la película dedica el mayor grosor a los episodios más conocidos y populares de las hazañas del hijo de Zeus: sus doce trabajos. Muchos conocerán cuáles son estos, pero ¿y el motivo que le llevó a hacerlos? En el film Hércules, de Roger Young, el aún adolescente Hércules se escapó una noche a un festival en honor a Hera en el que se encontraba su idolatrada Mégara. Dejándose llevar por la pasión pasaron la noche juntos y la muchacha se quedó embarazada de trillizos. Acusado de violación, Hércules se vio obligado a alejarse de Mégara y esta se prometió con Euristeo. Una vez que Hércules creció y estuvo preparado, volvió a Tebas y se encontró nuevamente con sus hijos, pero Mégara, devota de Hera y presa del mismo odio que Alcmena, quiso deshacerse del padre de sus hijos. Siguiendo pues los consejos de aquella, envenenó a Hércules haciéndole entrar en un estado de locura que le llevó a matar a sus tres hijos. Así, con la necesidad de sanar su culpa y tras consultar a Tiresias en el oráculo de Delfos, se puso al servicio de Euristeo, quien le encargaría los doce trabajos. Este episodio de la locura, tal como expone Ruiz de Elvira (2000),

... es colocado en este momento de la vida de Hércules por Apolodoro (II, 4, 12), Diodoro (Iv, 11, 1-3), Nicolás de Damasco (90F 13 en Constantino Porfirogénito exc. de virtut. I, 337, 13) y Mosco (Mégara vv. 13-16, 41-46); en cambio Eurípides en el Hércules [...] coloca la locura mucho después como posterior a los trabajos; en 


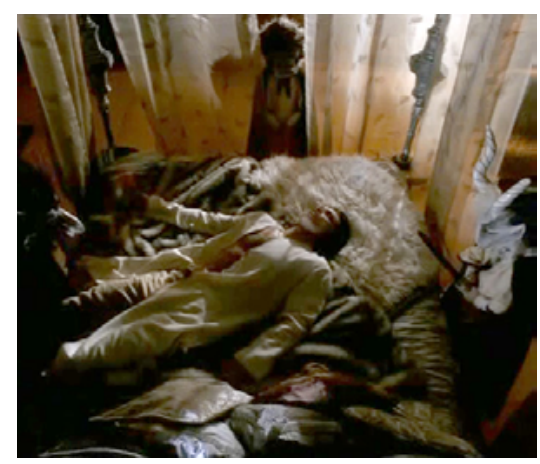

Fig. 9. Hércules en la cama es rodeado por sus hijos, que pretenden matarle.

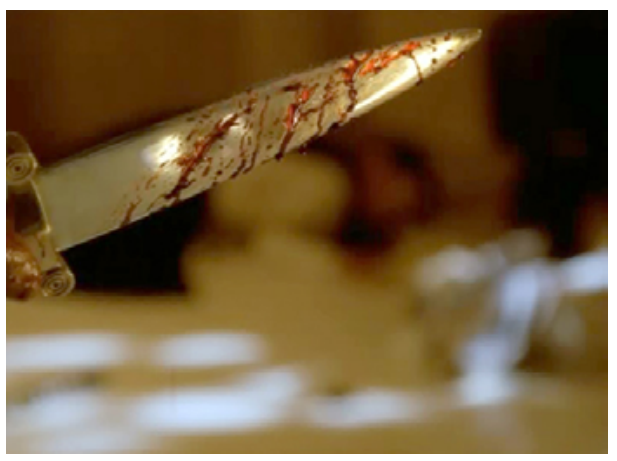

Fig. 10. Puñal ensangrentado con el que Hércules da muerte a sus hijos. Al fondo, se intuye la silueta de uno de los críos, que yace muerto.

Eurípides y sus seguidores, además, Hércules mata también a su esposa Mégara. En Apolodoro [...] Hércules mata a sus hijos, y también a los de Ificles, arrojándolos al fuego; en Eurípides [...] a flechazos y mazazos.

En el film, tras Hércules beber de la copa que Mégara la había servido con el veneno, los tres niños acompañados de Ificles acuden a la alcoba donde se encuentra su padre y comienzan a agredirle (fig. 9). Este, alentado por la voz de su hermano, que le susurra que los niños eran demonios, comienza a atacarlos con golpes y un puñal (fig. 10) hasta matarlos. A diferencia de algunas de las fuentes que exponen que además de a sus hijos mató a los de Ificles y a Mégara, en la película no puede ocurrir esto porque Ificles no tiene hijos y Mégara es, junto con Alcmena, la principal antagonista del personaje de Hércules, lo que supondría un fuerte giro en la trama de la película.

Herido y desolado, el Hércules de Young es cuidado por la ninfa Deyanira -con quien establecerá una relación y tendrá un hijo: Hilo-y acompañado por Linus acude al oráculo de Delfos, donde Tiresias - en la mitología sería este el momento en el que la Pitia le diera el nombre de Heracles- le dice:

Mégara es la esposa de Euristeo. Tú debes entregar tu poder y orgullo al servicio de su gloria. Seis veces debes servirlos, tres veces por tres hijos asesinados y tres veces por Hércules, muerto como un héroe, muerto como un dios, que debe renacer como un hombre.

Así, tras escuchar las palabras del vidente, el héroe regresará y se someterá a las órdenes de Euristeo. En este episodio, como podemos comprobar mediante el diálogo, el film altera el número real de trabajos que el tebano debe realizar. Esta modificación - de doce a seis trabajos- es entendible y lógica si comprendemos que un film, al fin y al cabo y por mucho que pueda alargar su minutaje, está 


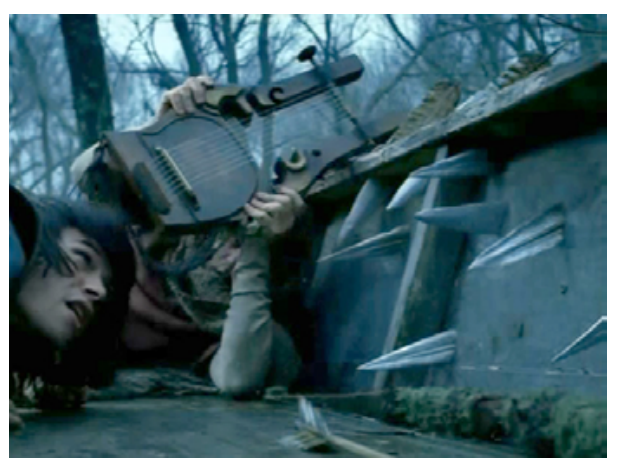

Fig. 11. Hércules y Linus se protegen del ataque de las aves.

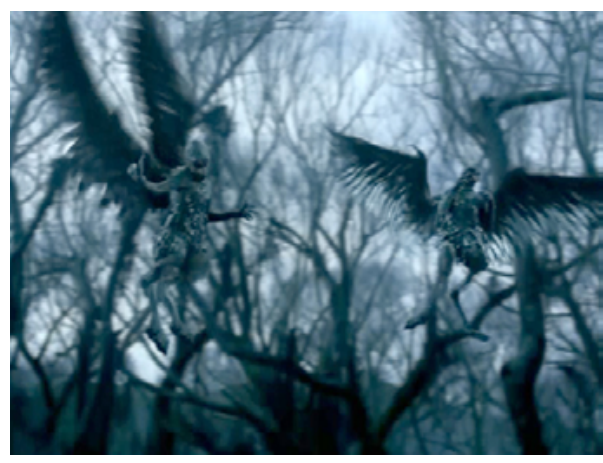

Fig. 12. Las harpías se muestran ante Hércules y Linus.

limitado por el tiempo. Además, esta producción concretamente ha sido, como hemos visto, más explícita, en otros ámbitos de la vida del héroe, lo que hace inevitable reducir esta historia, que, en cierto modo, es la más conocida de Hércules. Es probable que en su versión televisiva, de cuatro horas de duración, los trabajos fueran más, y que para esta versión se modificara el diálogo para ajustarlo al argumento que desarrolla.

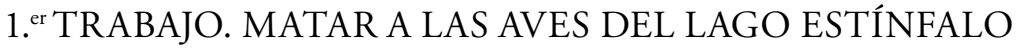

Euristeo ordena a Hércules como primer trabajo matar a las aves de Estinfalia. Para llevarlo a cabo, el joven debe acudir a «la remota tierra de Estinfalia», donde hay un pantano lúgubre debido a la presencia de unas extrańas aves que no permiten que el lugar florezca. Acompañado de Linus, el héroe llega hasta la morada de las aves en una barca y comienzan a «lloverles» plumas afiladas (fig. 11) como cuchillas que intentan matarlos. Las aves, en realidad las harpías que le habían dado el nombre de Hércules, se enfrentan a él, pero este finalmente acaba con ellas a flechazos.

Apolodoro (II, 5, 6) nos cuenta que este fue el sexto trabajo de Heracles y que en la ciudad de Estínfalo había un lago oculto por la vegetación donde se habían refugiado numerosas aves. El hijo de Zeus no sabía cómo hacerlas salir, así que Atenea le facilitó unos crótalos de bronce que hizo sonar en una montańa cerca del lago, y consiguiendo que las aves levantaran el vuelo las aturdió con una flecha.

Nuevamente las harpías (fig. 12) aparecen en el film totalmente descontextualizadas ya que, como adelantamos, estas no tienen relación con la historia de Heracles. Es aceptable, sin embargo, que el film las vuelva a utilizar en este aspecto para reflejar cómo Hércules va ganando terreno sobre las devotas de Hera, que son 


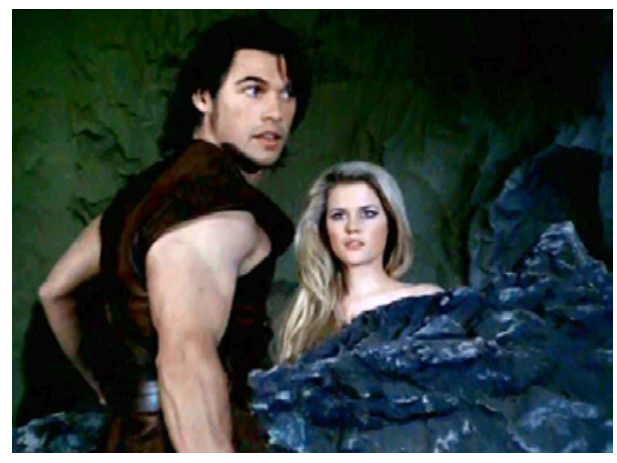

Fig. 13. Hércules y la mujer que habita en la cueva del león de Nemea.

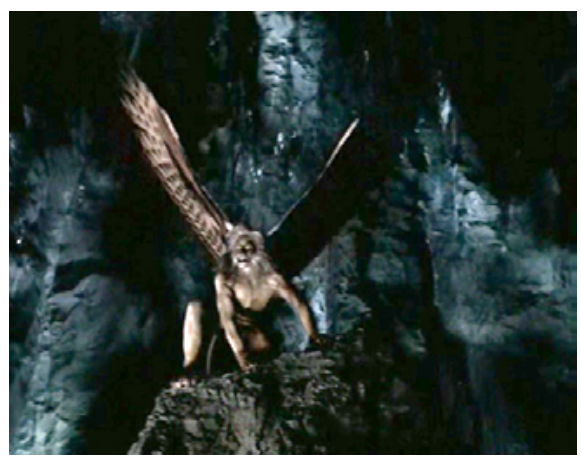

Fig. 14. La mujer transformada en esfinge amenaza a Hércules.

sus enemigas. Además de este aspecto, la película obvia la ayuda que el héroe recibe de la diosa Atenea, porque, como hemos visto, la presencia de los dioses no tiene cabida en este film, y, además, si Hércules se enfrenta a ellas por iniciativa propia, se exalta su carácter invencible y su heroicidad.

\section{2. ${ }^{\circ}$ TRABAJO. MATAR AL LEÓN DE NEMEA Y DESPOJARLO DE SU PIEL}

El segundo trabajo encomendado por Euristeo en el film es el de matar al león de Nemea, una de las hazañas más importantes, y que caracteriza la iconografía del héroe por representársele habitualmente ataviado con la piel de este animal. Según Hesíodo (Teogonía, 327 ss.) el león de Nemea fue criado por Hera, quien lo puso en los montes de Nemea y fue Heracles quien le dio la muerte. Apolodoro (II, 5, 1), por su parte, describe mejor esta escena declarando que cuando Heracles llegó a Nemea, disparó al león primero con flechas, pero como vio que era invulnerable, lo persiguió con la maza. El animal se refugió en una cueva con dos entradas, así que el héroe tapó una de ellas y se enfrentó a la fiera rodeándole el cuello con sus brazos hasta estrangularla. En la película, sin embargo, la hazaña no ocurre exactamente de esta manera. Hércules se adentra en la cueva en la que presuntamente está el león y se encuentra con una joven mujer de cabello rubio (fig. 13), que pide al héroe que se acerque y la bese. Tras obedecer su petición, el joven se atreve a preguntarle por el león y esta, sin permitir una reacción de Hércules, se transforma -según palabras de Linus- en una esfinge (fig. 14). La realidad es que, según los textos, una esfinge griega -diferente a la egipcia- se caracteriza por tener rostro y pecho de mujer; cuerpo, zarpas y cola de león; estar cubierta de plumas y generalmente alada. El ser del film, sin embargo, presenta cuerpo humano -al igual que el Minotauro-cubierto de pelo, cabeza de león y unas alas similares a las de un águila. 


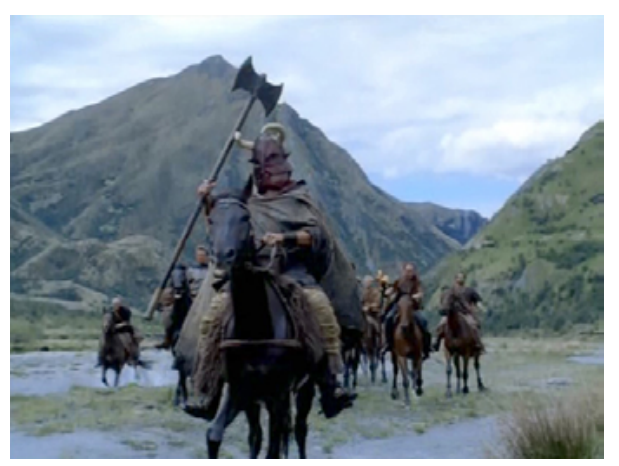

Fig. 15. Anteo como el toro de Creta.

Este cambio, que parece irrelevante, transforma por completo la principal hazaña por la que en la cultura se conoce al héroe griego. Este cambio, quizás, se produce por el interés en buscar un espécimen más espectacular y que se aproxime más a la fantasía que es habitual en un ser «mitológico». Con esto quiero decir que, casi con toda seguridad, el espectador relaciona más fácilmente con la mitología a un animal inexistente y que parece invulnerable que a un simple «león». A este cambio, hay que añadirle, además, la extraña manera en la que Hércules da muerte al animal. Tras intentar abatirlo con flechas -como en los textos-, el fornido joven se enfrenta a la bestia con sus brazos, pero en lugar de estrangularlo con su fuerza hace que esta se abra el pecho con sus propias zarpas.

\section{$3{ }^{\text {er }}$ TRABAJO. CAPTURAR AL TORO DE CRETA}

Según la película, tras haber sido desolada una aldea próxima a Tirinto, Euristeo encomienda a Hércules apresar al toro de Creta y traerlo con vida. Este «toro de Creta» es en realidad Anteo (fig. 15) -hijo de la madre tierra y supuesto padre de Hércules-, que porta un casco con cuernos y, junto con otros hombres, está atemorizando a la población destruyendo sus hogares. Hércules, junto con los hombres de la aldea, se enfrenta a Anteo, lo captura y lo presenta ante el rey, quien lo encerrará en una torre, alejado de la tierra de donde toma la fuerza.

Nada más lejos de la realidad de los mitos. Según Pausanias (Descripción de Grecia I, 27, 9) los cretenses creían que Posidón les había enviado al toro porque Minos rendía menos culto a este dios que a otros. Cuenta en relación con este animal que fue llevado desde la isla hasta el Peloponeso y que constituyó uno de los trabajos de Heracles. Apolodoro (II, 5, 7) expone, sin embargo, que este fue el séptimo trabajo de Heracles y que este se desplazó hasta Creta a buscarlo. Una vez que lo capturó, lo llevó ante Euristeo, quien lo dejó libre provocando que vagara por Esparta, Arcadia e Istmo hasta llegar a Maratón. 


\section{4. ${ }^{\circ}$ TRABAJO. ROBAR LAS YEGUAS DE DIOMEDES}

Expone Eurípides (Heracles, 380 y ss.): «Heracles subió a su cuadriga y con la brida domó las yeguas de Diomedes». Este octavo trabajo, en palabras de Apolodoro (II, 5, 8), corresponde al cuarto que en este caso Mégara encomienda a Hércules en el film. En esta hazaña el héroe debe ir a la isla de Lemos y domar a las yeguas antropófagas trayendo como prueba el ceñidor dorado que lleva la líder de la manada. Después de la travesía lo que Hércules se encuentra en la isla es un grupo de mujeres encabezadas por su reina, Hipólita, que se trasforman en yeguas una vez al año y comen carne de hombre. Así, Hércules y otros voluntarios que le acompañaban se enfrentaron a ellas, «las domaron» y el héroe quitó el ceñidor dorado, destruyéndolo finalmente delante de Mégara y Euristeo para que las yeguas no puedan volver a celebrar su festival sangriento anual. Poco tiene que ver esta escena con los textos clásicos ya que, además de obviar la figura de Diomedes -en Apolodoro II, 5, 8, un tracio hijo de Ares y Cirene y rey de los bístones-, nada se habla en ellos de un grupo de mujeres. Sin embargo, este cambio podría explicarse si examinamos la tendencia constante del film a enfrentar a ambos sexos: Zeus/Hera, Anfitrión/Alcmena, Mégara/Hércules. De esta forma, que el protagonista medie y apacigüe a las mujeres/yeguas habla de su interés por romper con la rivalidad entre ambos géneros. De este modo, su figura nuevamente heroica hace de mediador para conseguir el equilibrio que tanto se menciona durante el largometraje.

Además de esto, como se puede intuir tras la descripción que se ha hecho sobre la escena, este cuarto trabajo encomendado a Hércules en el film incluye-aunque de forma enmascarada- el noveno trabajo expuesto por las fuentes: el cinturón de Hipólita. En este episodio, Heracles tuvo que robar el cinturón de Ares que ostentaba Hipólita, reina de las amazonas, porque la hija de Euristeo quería poseerlo. Tras desembarcar en la isla de Paros, el héroe tuvo un enfrentamiento con los hijos de Minos y cambió su rumbo. Así, Hipólita se presentó antes Heracles para preguntarle por qué le buscaba y le prometió entregarle el cinturón. Sin embargo, Hera, convertida en amazona, comenzó a alarmar a las demás mujeres haciendo creer que su reina había sido secuestrada. Hércules, tras ver como llegaba la multitud contra él y creyendo haber sido engañado, mató a Hipólita, le robó el cinturón y embarcó rumbo a Troya (Apolodoro, II, 5, 9).

\section{5. ${ }^{\circ}$ TRABAJO. CAPTURAR A LA CIERVA DE CERINEA}

Como quinto trabajo, Euristeo quiere poner a prueba a Hércules retándolo a abatir a la cierva de Cerinea -animal vinculado a su esposa Deyanira y a su hijo Hilo, de quien es su animal de compañía-. Aceptando el reto, se adentran en el bosque con el fin de dar caza al animal. Hércules, que no quiere dañarlo, siéndole fiel a su hijo, le dispara una flecha entre los tendones y los huesos y así gana a Euristeo y consigue que la cierva salga ilesa. Esta idea de piedad que muestra el protagonista surge directamente de las fuentes y es que, como cuenta Apolodoro, Heracles, para no herir ni matar a este animal consagrado a Artemis, lo persiguió durante un año 
entero hasta que la cierva cayó fatigada y pudo llevarla viva hasta Micenas, tal como pidió Euristeo. Aunque en la fuente no existe la competición entre Euristeo y Hércules. Lo que pretende el film con esta modificación, además de incrementar la rivalidad entre los dos hombres, es mostrar la mezquindad del rey que pretende matar al animal con el que Hilo, que es solo un niño, está tan unido. De esta manera, el espectador recrea inmediatamente una imagen mezquina del villano y una imagen bondadosa del héroe.

\section{6. ${ }^{\circ}$ TRABAJO. CAPTURAR AL CAN CERBERO Y SACARLO DE LOS INFIERNOS}

El sexto y último trabajo del Hércules de Young supone ir en busca de Cerbero, el perro de tres cabezas que cuida la entrada al Hades, y traerlo hasta Tirinto. Sin embargo, cuando Hércules llega hasta el río Estigia y se adentra en la cueva donde debiera estar el can no hay rastro de él, encontrándose en su lugar a Anteo, a quien se enfrentará y dará muerte. Sabiendo que Anteo ha sido el principal obstáculo de Hércules y el único que, por su físico, se puede enfrentar al fornido héroe, es razonable que su personaje se «recicle» y encarne más de uno de los trabajos que este tiene que realizar. En este sentido, Anteo, siendo para el protagonista un rival difícil, hace que con su derrota se glorifique aún más la figura de Hércules y sus trabajos concluyan de forma victoriosa.

Además de estos seis, a lo largo del film se desarrollan, aunque no como tales, otros de los trabajos que se le atribuyen a Heracles dentro de los textos clásicos. Así, podemos contemplar en otras escenas del metraje la lucha contra el jabalí Erimanto y el duelo contra la hidra de Lerna.

- El jabalí de Erimanto. Estando ya exiliado en las montañas a cargo del ganado de su padre, Hércules, con el fin de demostrar su hombría, intentó - corriendo tras él- dar caza al jabalí que espantaba a las reses que estaban bajo su responsabilidad. Unido pues a Anfitrión, Ificles, Mégara, Euristeo y Teseo, el aún adolescente héroe se enfrentó cuerpo a cuerpo al animal (fig. 16) que denominan "Colmillo Mellado", saliendo herido de la reyerta. Fue realmente la ninfa Deyanira quien lo abatió con un flechazo - con el fin de salvar a Hércules-y Euristeo quien lo mató definitivamente clavándole una lanza. Como se hace obvio, las fuentes no recogen esta escena como una cacería conjunta. De este modo, el considerado como cuarto trabajo fue realizado únicamente por Heracles, quien no dio muerte al animal (Apolodoro II, 5, 4).

- La hidra de Lerna. Pasaron los años y, aislado en las montañas, Hércules se entrenó a diario cargando un caballo a sus espaldas, convirtiéndose así en un joven fuerte. Siendo ya todo un hombre, la ciudad de Tebas estaba amenazada por la presencia de un ser aterrador, la hidra de Lerna, que en el film se nos presenta con aspecto de monstruo marino de dos cabezas. Creyendo el joven que esta era una buena oportunidad para ganarse la gracia de la población de su ciudad natal, acudió a enfrentarse al monstruo. Una vez allí, Hércu- 


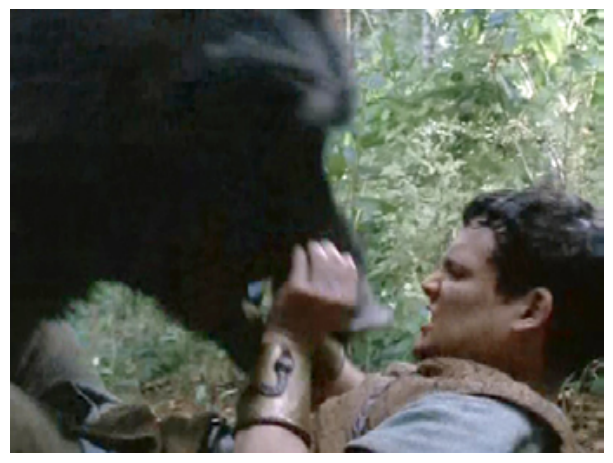

Fig. 16. Hércules adolescente forcejeando con Colmillo Mellado (jabalí de Erimanto).

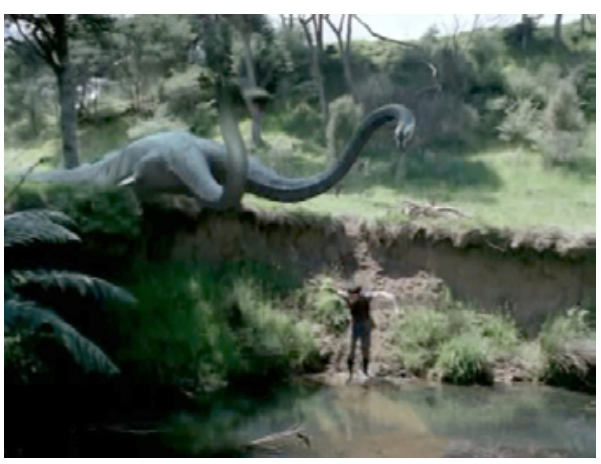

Fig. 17. Hércules enfrentándose a la hidra de Lerna.

les se enfrentó a la hidra (fig. 17), a la que, al igual que en las fuentes, se le multiplicaban las cabezas si se le cortaba una. Por ello, Hércules, que además de en fuerza había crecido en astucia, mandó a Linus a quemar los cuellos de las cabezas cortadas para que no se pudieran reproducir. Ya muy debilitada, Hércules da muerte a la hidra con un tronco de árbol que, en cierto modo, se puede relacionar con el garrote o la maza que se vincula con el héroe mitológico como atributo iconográfico.

Según Hesíodo (Teogonía, 313 y ss.):

... la perversa Hidra de Lerna, a la que alimentó Hera, diosa de blancos brazos, irritada terriblemente con el fornido Heracles. La aniquiló el hijo de Zeus con su implacable bronce, el Anfitriónida Heracles, con ayuda del belicoso Yolao, según los planes de Atenea amiga de botín.

Las palabras de Hesíodo sin duda hacen alusión a la hazaña del héroe griego, pero sin embargo es el texto de Apolodoro (II, 5, 2) el que nos permite hacer una conexión más lógica y coherente con la escena del film. Así, según este:

De nada servía golpear las cabezas con la maza, pues cuando aplastaba una surgían dos. [...] pidió ayuda a Yolao, quien, después de incendiar parte de un bosque cercano, con los tizones quemó los cuellos de las cabezas e impidió que resurgieran. Evitada así su proliferación cortó la cabeza inmortal...

En ambos casos, se nos habla de la presencia y ayuda de Yolao. En el film, por su parte, esta figura es sustituida por la de Linus y tiene sentido si contamos con que inmediatamente después de esta escena, el que fuera maestro de música del héroe se entregará como fiel servidor y será quien le acompañe en todas las aventuras del resto de su vida. 


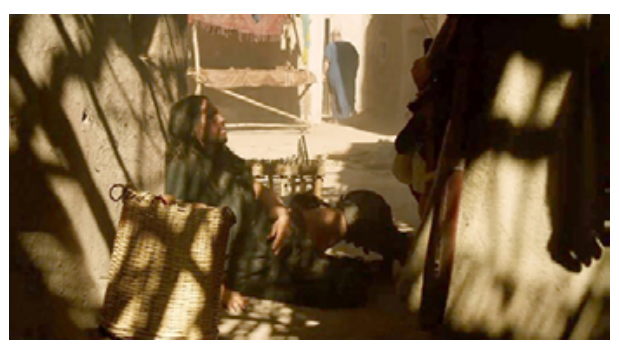

Fig. 18. Hércules ebrio tirado en las calles de la ciudad.

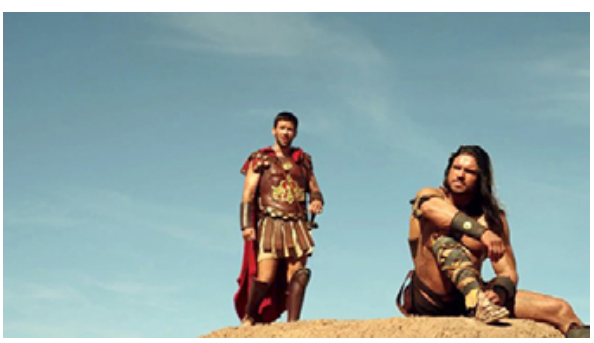

Fig. 19. Hércules y Arius antes de enfrentarse al rey Nicos.

\section{HERCULES REBORN (2014), NICK LYON}

En este largometraje dirigido por Nick Lyon, el personaje de Hércules queda absolutamente descontextualizado del mito que nos exponen las fuentes. Podemos afirmar en realidad que no hay rastro en absoluto de la personalidad de nuestro héroe, y que su nombre se usa como excusa para dar rienda suelta a la imaginación de los guionistas, los cuales introducen personajes que no existen en este mito, ni en ningún otro de las fuentes clásicas -Nicos, Aticus Dudunakus, Timek...-. A pesar de esto, y de la gran distorsión que sufre la historia, en esta producción se puede establecer una única conexión con el mito, y es, aunque no por la misma causa, la muerte de Mégara y sus hijos. En relación con esto, Hércules, mata a su esposa e hijos porque Nicos, enamorado de Mégara, hace que el héroe ingiera una poción que lo vuelve loco y agresivo lanzando una escultura de piedra contra su familia, causándole la muerte. Como ya hemos comentado respecto a este episodio, Apolodoro (II, 12, 1) expone que

después del combate contra los minias, Hera, celosa, lo enloqueció y Heracles arrojó al fuego a sus hijos habidos con Mégara y a dos de Ificles; por ello se condenó a sí mismo al exilio y, purificado por Tespio, marchó a Delfos y preguntó al dios dónde debería vivir.

En este film se pretende mostrar a un Hércules destruido después de su vida gloriosa. Así, lo que podemos ver en él es un Hércules retirado de la "vida pública», ahogado en el alcohol (fig. 18) y destrozado por haber matado a su esposa e hijos. Hércules es aquí el antihéroe tan característico del cine de las últimas décadas. Es inquietante cómo en una película de estas características se ha caído en uno de los mayores tópicos del cine y de la vida en general: un héroe -o un hombre de éxitofrustrado se refugia en el alcohol -o cualquier tipo de estupefaciente- para ser rescatado (fig. 19) y renacer de sus cenizas como un ave fénix.

A pesar de esta condición, que es la que primeramente nos muestra el largometraje, su figura sigue creando expectación y sus hazańas del pasado hoy se cuentan 


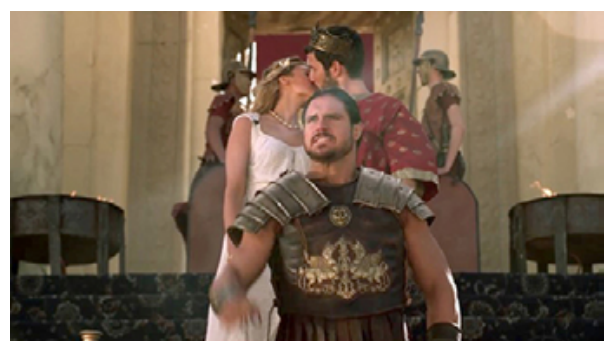

Fig. 20. Hércules se planta victorioso frente al pueblo que le aclama por librarle de un rey tirano.

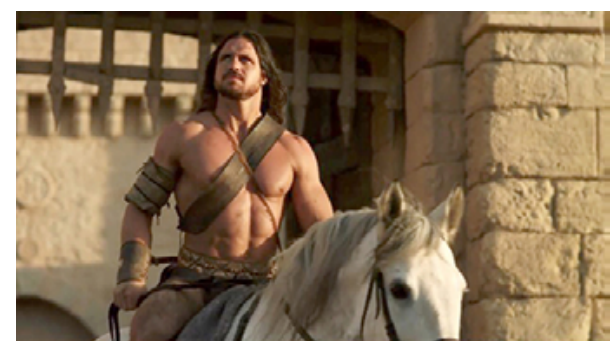

Fig. 21. Hércules «renacido», marcha rumbo hacia una nueva vida.

como leyendas entre los jóvenes. Lo cierto es que Aticus, nuestro personaje principal, que se concibe ahora como el héroe del héroe y quizás un alter ego del antiguo Hércules, sabe que este existe realmente y por ello acude en su búsqueda para que luche con él y salvarlo de su versión más denigrante.

\section{THE LEGEND OF HERCULES (2014), RENNY HARLIN}

The Legend of Hercules (Hércules: el origen de la leyenda), es la segunda producción cinematográfica realizada en el año 2014 sobre el héroe heleno hijo de Zeus y Alcmena. Este film se inicia ubicando al espectador en medio de una batalla en la localidad de Argos en el año 1200 a.C. donde finalmente se baten en duelo el rey Galeano de Argos y el rey Anfitrión de Tirinto. A este último, la película lo presenta como un tirano y codicioso rey, por lo que Alcmena, su mujer, temerosa por el hijo que tienen en común, Ificles, y por la reacción de los dioses ante la actitud de su esposo, reza a Hera para que esta medie ante su rey. Así, la diosa se presenta en forma humana a ella y su tutor Quirón y le pregunta a la mortal si está dispuesta a traicionar a su esposo para tener un hijo de Zeus y conseguir la paz en su tierra. De esta manera, Hera anuncia a Alcmena que concebirá a un hijo de Zeus y que ella le conocerá siempre como Hércules. Así, en forma de tormenta eléctrica, Zeus toma a la mortal mientras está en su lecho y engendra al héroe que traerá la paz.

Tras la gestación, Alcmena da a luz a su segundo hijo y Anfitrión, que sabe que no es suyo y le ha declarado "la guerra» a Zeus, dice ante su esposa: «Se llamará Alcides y nunca se tratará como un igual a su hermano mayor».

Como vemos, este film, dirigido por Renny Harlin, hace una lectura no muy fiel de la concepción y el nacimiento de Heracles que exponen las fuentes clásicas. De acuerdo a estas, como hemos visto ya anteriormente, Heracles es concebido por un «capricho» de Zeus y nada tiene que ver Hera, que, contrariamente a la película, actuará en contra del muchacho toda su vida y, por supuesto, no mediará para que Alcmena geste en su vientre a un hijo de su esposo. En este aspecto, aunque parezca 
que el cambio de rol que sufre Hera en el film con respecto a las fuentes no tiene cabida, lo cierto es que puede tenerla si nos paramos a pensar que, contrariamente a Anfitrión, Alcmena venera y defiende a los dioses. Además, cuando pide ayuda para acabar con la tiranía y mezquindad de su rey es a una representación de Hera a la que le ora. De ahí, quizás, el porqué de que sea esta diosa la que, en el film, media en la concepción de Hércules, convirtiéndose de algún modo en la salvadora.

A pesar de las modificaciones, este film introduce un aspecto que ningún otro de este siglo hace: presentar al héroe con su verdadero nombre de pila. Aunque parezca intrascendente, este hecho es curioso y diríamos incluso que atrevido, ya que el nombre de Hércules está tan arraigado en la cultura universal que, a excepción de las personas que trabajan, estudian o se interesan de manera profunda en la mitología, la mayoría del público podría no llegar a entender el «cambio» de nombre y considerarlo incluso "gratuito». Lo cierto es que el verdadero nombre de Heracles era, según los mitógrafos, Alcides o Alceo, viniendo este de su abuelo paterno. En palabras de Diodoro de Sicilia (I, 24, 4): «El de Alcmena [...] fue llamado Alceo al nacer y más tarde se le cambió el nombre por el de Heracles». Sin embargo, Apolodoro (II, 4, 12), por su parte, expone: «La Pitia entonces lo llamó por primera vez Heracles, pues antes era conocido por Alcides [...]». Este aspecto, recogido por el film, es especialmente interesante ya que, tal como expone Dan Curley (2018): "... the movie delves into Hercules' backstory and thus breaks with the cinematic norm of the fully formed and seasoned herom. ${ }^{13}$

Veinte años más tarde, según el film, Alcides, ya en la etapa adulta y con un cuerpo notablemente atlético, establece una relación sentimental con la princesa Hebe, hija del rey Tallas de Creta. Sin embargo, su hermano Ificles, celoso de la pareja, convencerá al rey Anfitrión -que detesta firmemente a Hércules-para que rechace la unión de ambos y sea él quien despose a la princesa. Lo cierto es que en la mitología Heracles y Hebe se unen en matrimonio (Ovidio, Fastos vi, 65) después de que este realice su última hazaña, la cual le llevará a la muerte terrenal: la lucha en Ecalia. Según las fuentes, tras la victoria, pretende hacer un sacrificio de acción de gracias a Zeus y ordena a Deyanira -su esposa por entonces- que le haga llegar su atuendo para los sacrificios. Así, la ninfa, que estaba insegura de que Heracles la amara, impregnó la capa con un filtro ${ }^{14}$ que el centauro Neso antes de morir le había aconsejado. Lo que no sabía Deyanira es que realmente la sangre de Neso estaba envenenada suponiendo su filtro un verdadero ungüento tóxico. Así, cuando Heracles puso la túnica sobre sí se le quemó la piel causándole terribles lesiones incurables y, debido a su gran dolor, pidió que le hicieran arder en una pira en el monte Eta. De este modo, con las llamas, murió su parte mortal y la inmortal subió al Olimpo. Es en este momento cuando, tras reconciliarse con Hera, toma en matrimonio a Hebe,

${ }^{13}$ La película se adentra en la historia de Hércules y rompe así con la norma cinematográfica del héroe plenamente formado y experimentado. Traducción de la autora.

${ }^{14}$ Una especie de poción hecha con el semen y la sangre del centauro Neso mezclada con aceite. 


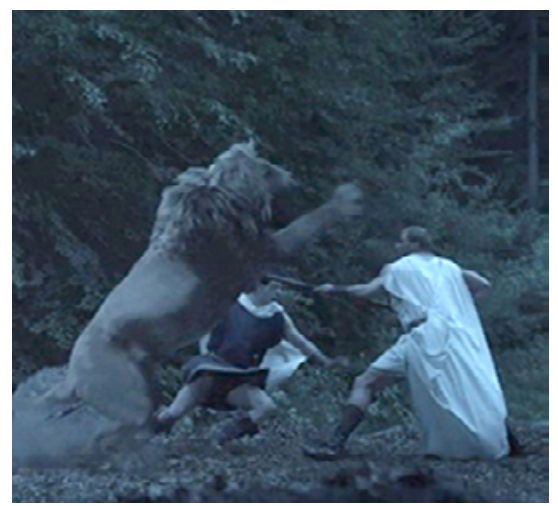

Fig. 22. Hércules intentando clavar una lanza al león.

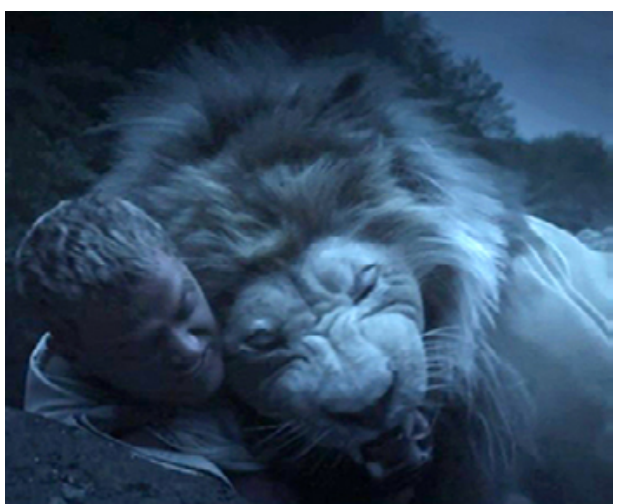

Fig. 23. Hércules ahogando al león con sus propios brazos.

hija de la diosa, con la que, según Apolodoro (II, 7, 7), tendrá dos hijos: Alexíares y Aniceto $^{15}$. En palabras de Diodoro de Sicilia (Iv, 39, 2):

... después de su apoteosis, Zeus persuadió a Hera para que adoptase a Heracles como hijo y le diese un afecto maternal durante todo el resto de los tiempos. Esta adopción se realizó, dicen, del modo siguiente: Hera se subió al lecho y, tras atraer junto a su cuerpo a Heracles, dejó que se deslizara al suelo a través de sus vestidos, imitando un verdadero nacimiento. Esto precisamente es lo que hacen los bárbaros hasta nuestros días cuando quieren adoptar un hijo. Después de la adopción, Hera, cuentan los mitos, unió a Heracles en matrimonio a Hebe.

Además de esta relación, la producción, antes de modificar por completo la historia del héroe, mandándolo a luchar a Heliopolis (Egipto) y ser vendido como gladiador, hace alusión a uno de los doce trabajos que exponen las fuentes: el enfrentamiento al león de Nemea. Así, Alcides, paseando a caballo con su hermano mayor Ificles, se encuentra por casualidad con el león de Nemea, al que sin dudarlo hace frente. Tras enfrentarse a él con lanzas (fig. 22) y ver que su dura piel no permite que la moharra ${ }^{16}$ le dañe, Alcides se enfrenta al enorme animal con sus propias manos (fig. 23) y lo mata apretándole el cuello hasta estrangularlo. Aunque como vemos la historia no ocurre como exponen las fuentes, en esta hazaña el film es fiel a la hora de mostrar la forma en la que el héroe da muerte a la fiera. De este modo, aunque varía el resto del trabajo, con esta acción la película consigue subrayar el lado sobre-

15 Al final de la película Hebe y Hércules tienen un hijo.

${ }^{16}$ Como se denomina la punta metálica de una lanza. 


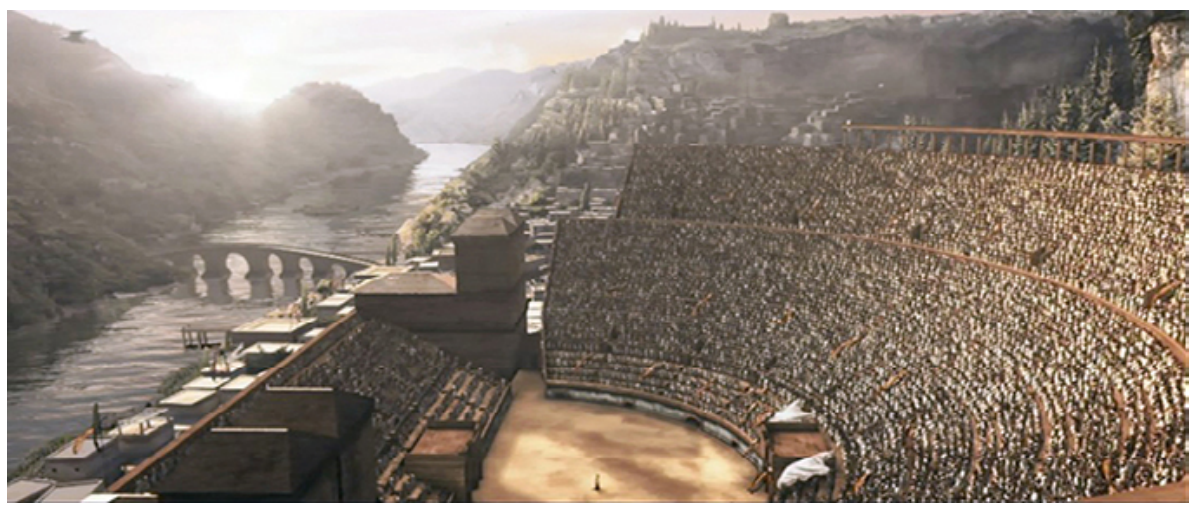

Fig. 24. Teatro que recoge la última lucha de Hércules como gladiador.

humano y la fuerza espectacular del personaje, aspectos principales que interesan de la figura de Alcides para este tipo de adaptaciones.

Tras esta hazaña, Anfitrión anuncia que Hebe deberá desposarse con el heredero del trono de Tirinto, Ificles, condenando así su unión con Alcides. La pareja, aturdida por la decisión del rey, que va en contra de su voluntad, huye con el deseo de formar una nueva vida juntos. Sin embargo, son apresados y Hércules, por desobedecer las órdenes de su rey, es enviado - como ya adelantábamos-a luchar con los soldados del ejército de Tirinto al estrecho de Osiris en Egipto ${ }^{17}$. Allí, serán vencidos y los dos únicos supervivientes, Alcides y Sotiris - general del ejército-, son capturados por Tarak, cabeza del ejército enemigo. Este los venderá como esclavos y pasarán a pertenecer a un lanista ${ }^{18}$ que los llevará de un lado para otro como gladiadores. Respecto a este detalle, nos vemos en la obligación de aclarar que si tenemos en cuenta que la película nos sitúa desde el principio en el año 1200 a.C. y pasan 20 años hasta que Alcides e Ificles son adultos, esta escena tendría lugar aproximadamente en el año 1180 a.C., por tanto habría que matizar que el tráfico de gladiadores ocurre siglos más tarde, desde el siglo vi a.C., cuando los milicianos etruscos luchaban entre sí para honrar a los difuntos de las clases influyentes de la sociedad, y que este "comercio» nada tiene que ver con los griegos. Nuevamente, pues, se trata de una licencia que se toman los guionistas y el director del film conduciendo la historia hacia una absoluta descontextualización.

Este hecho en realidad es más propio de lo que parece de este tipo de péplums. Es frecuente que en estos films recreados en la antigua Grecia se incluyan algunos aspectos de, principalmente, la cultura y la historia de Roma, que poco o nada tie-

${ }^{17}$ Esta escena nos recuerda de forma clara a la lucha que se desarrolla entre Leónidas (y los espartanos) contra los persas en el film de Zack Snyder, 300.

${ }_{18}$ Propietario y formador de gladiadores. 
nen que ver con ella. Este ejemplo suscitado en Hércules: el origen de la leyenda es solo uno de los muchos que se producen en películas de esta índole. Lo cierto es que la civilización romana ha llegado hasta nuestros días con estudios mucho más amplios y profundos que la griega, y también lo es que somos conocedores de la civilización helena gracias a que los romanos tomaron muchos aspectos de ella. Sin embargo, no debemos olvidar que entre ambas culturas también hay divergencias que las hacen más diferentes de lo que se cree de manera general.

Regresando nuevamente al film, tras haber viajado por diferentes partes del mundo como gladiador, nuestro protagonista se fue fraguando una reputación dentro del mundo de los combates bajo el nombre de Hércules, regalo de Hera. Finalmente el héroe llega a Tirinto, donde pide a su dueño la libertad si consigue salir victorioso contra los seis gladiadores más fuertes de toda Grecia. Así, Hércules, junto con Sotiris y su antiguo ejército, luchará contra el tirano Anfitrión y su hijo Ificles, encabezando pues una revolución ante un rey nefasto. Finalmente, aceptando ser hijo de Zeus, Hércules se enfrenta a su "padre» en la tierra y vence a su mezquindad y avaricia.

En este film, pues, Hércules pasa de ser un héroe de hazañas sobrehumanas a un soldado que lucha por el cometido para el que, según Hera, había nacido: conseguir la paz en su tierra. En definitiva, estas características que sigue el personaje del film son más propias de la concepción que se tiene sobre el héroe ya en la civilización romana: «En Roma, la leyenda que se impuso en la época clásica es una aplicación del esquema de la lucha victoriosa del héroe benefactor contra el "malvado" malhechor» (Bonnefoy, 1997).

\section{HERCULES (2014), BRETT RATNER}

«¿Creéis que sabéis la verdad sobre él? No sabéis nada». Este film dirigido por Brett Ratner supone la última producción que se ha realizado en el siglo xxı en relación con el mito del héroe griego. En ella, una voz en offinicia el metraje y actúa como narrador omnisciente poniendo en contexto al espectador describiendo supuestos hechos de la vida del protagonista. De este modo, a medida que habla el relator, se nos presenta al personaje principal como un semidiós hijo de Zeus y Alcmena, odiado por la mujer del dios, Hera, la cual considera a este niño como un insulto y el vivo recuerdo de la infidelidad de su esposo. Alcmena, con el fin de apaciguar el odio de la diosa, llamó a su hijo Hércules, que significa gloria de Hera, como ya vimos; sin embargo, esto no consiguió calmar a la diosa, que continuaba deseando su muerte. A la par que se nos narra esta última frase, el film nos muestra a dos serpientes saliendo de los ojos de una estatua de Hera (fig. 25) y cómo las mismas se deslizan hasta la cuna del niño -ya con unos cuantos años- y este las estrangula con sus manos. Lo cierto es que, como ya hemos comentado, en las fuentes es efectivamente Hera quien manda los dos reptiles para intentar acabar con el niño ilegitimo; sin embargo, a diferencia de lo que vemos en el film, este era solo un recién nacido -o, como exponen otros, tendría solo 8 o 10 meses-. 


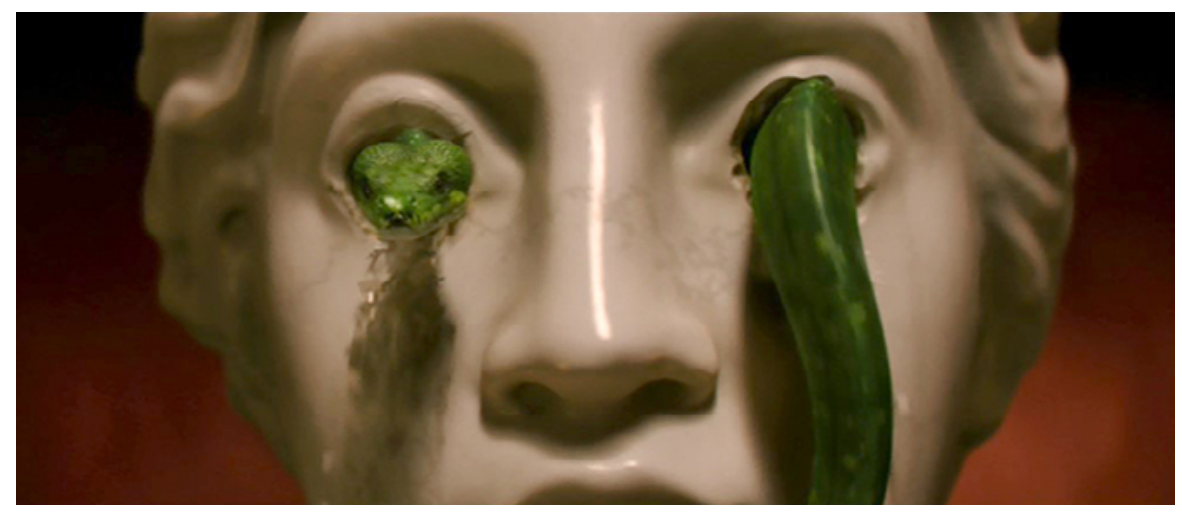

Fig. 25. Serpientes saliendo de los ojos de una estatua de Hera con intención de acabar con el pequeño Hércules.

Ya en la madurez, según continúa exponiendo el narrador en el film, a Hércules los dioses -según la mitología es Euristeo- le encomendaron doce trabajos, cumplidos los cuales, si sobrevivía, Hera accedería a dejarlo vivir en paz al fin. Entre ellos, la voz en off explica, mientras somos testigos de las hazańas, tres de los trabajos: la hidra de Lerna, el jabalí de Erimanto y el león de Nemea.

- La hidra de Lerna. En una especie de pantano Hércules sigilosamente porta una espada y cuando aparece la hidra se enfrenta a ella cortándole las cabezas. De este ser, no podemos identificar más que las partes que sobresalen del agua, distinguiendo así cinco cabezas con un aspecto similar a la de un dragón.

En los textos son diferentes las descripciones que se hacen sobre la hidra. Así, se habla que esta podría tener cien (Diodoro de Sicilia Iv, 11, 5), mil (Eurípides: Heracles, 419 y ss.) u ocho o nueve cabezas. En palabras textuales de Apolodoro (II, 5, 2):

Como segundo trabajo le ordenó matar a la Hidra de Lerna. Ésta, criada en el pantano de Lerna, irrumpía en el llano y destruía el campo y los ganados. La Hidra tenía un cuerpo enorme, con nueve cabezas, ocho mortales y la del centro inmortal. [...] De nada servía golpear las cabezas con la maza, pues cuando aplastaba una surgían dos. Un enorme cangrejo favorecía a la Hidra mordiendo el pie de Heracles. Él lo mató y luego pidió ayuda a Yolao, quien, después de incendiar parte de un bosque cercano, con los tizones quemó los cuellos de las cabezas e impidió que resurgieran. Evitada así su proliferación cortó la cabeza inmortal, la enterró y le puso encima una pesada roca, cerca del camino que través de Lerna conduce a Eleúnte. Abrió el cuerpo de la Hidra y sumergió las flechas en su bilis...

- El jabalí de Erimanto. En un bosque nevado, Hércules y un jabalí de descomunales dimensiones y tres pares de colmillos se enfrentan cara a cara. El semidiós consigue darle muerte golpeándolo con su mazo en la cabeza. 
En las fuentes, por el contrario, el héroe no debía matar al animal ya que el rey Euristeo lo pidió vivo ante él.

... cuando oyó la noticia de que los héroes se reunían, apenas hubo recorrido el camino de la Arcadia a Argos Lircea, por donde traía vivo el jabalí que pastaba en los valles de Lampea por la vasta marisma del Erimanto, de sus anchas espaldas lo descargó, envuelto en ataduras, a la entrada de la plaza de Micenas, y él por propia voluntad contra los planes de Euristeo partió (Apolonio de Rodas, Argonáuticas, I, 127).

- El león de Nemea. Según el narrador este es su mayor trabajo. En el interior de una cueva, Hércules se encuentra con un gigantesco león que no se inmuta en absoluto con las flechas que aquel le dispara, por ello enfrentándose a él cuerpo a cuerpo lo derrota rompiéndole la mandíbula.

Como ya sabemos, lo que nos transmiten las fuentes sobre este tema es que Heracles dio muerte a la fiera con sus propias manos, pero no dislocándole el maxilar inferior sino apretándole el cuello hasta estrangularlo.

Aunque los trabajos hayan sido narrados y mostrados en el comienzo del film -más tarde también mencionarán las manzanas de las Hespérides y el cinturón de Hipólita-, lo cierto es que la trama de la película nos hará ver que estos son una ficción para el «verdadero» Hércules. En este sentido, el hijo de Zeus se presenta como un mercenario cazarrecompensas que trabaja para reyes de toda Grecia en compañía de Autólico ${ }^{19}$, Atalanta ${ }^{20}$, Anfiarao ${ }^{21}$, Tideo $^{22}$ y Yolao. Este último es sobrino de Hércules -al igual que en las fuentes, pues es hijo de Ificles- e historiador - de ahí que sea el narrador que recita los trabajos de su tío-. Con esto, el largometraje nos presenta a un Hércules mitológico, pero sin serlo verdaderamente. Es decir, el Hércules de Rattner es un mercenario extremadamente fuerte, luchador y guerrero cuya fama, cantada por Yolao, se inspira en las hazañas del héroe de las fuentes clásicas, aunque no está claro que el de la película las haya vivido. En relación con esto Curley (2018) plantea que

Hercules goes further and adopts the atheistic approach of Troy, not only keeping divinities off screen, but also obscuring all evidence of their being. Both gods and

19 En la mitología, Autólico fue quien enseñó a Heracles, en su juventud, el arte de la lucha.

20 Atalanta es una heroína de la mitología que fue abandonada por su padre en el bosque, siendo amamantada por una osa hasta que la rescataron unos cazadores y la criaron. Ya de adulta se mantuvo virgen y, al igual que Ártemis, se dedicó a cazar en los bosques. Este personaje no tiene ningún tipo de relación con el mito de Heracles.

${ }_{21}$ Anfiarao tampoco tiene vínculo con el mito del héroe tebano, sin embargo, las características del personaje del film coinciden con las del mitológico. Así, Anfiarao era realmente un vidente que gozaba de la protección de Zeus y Apolo y, del mismo modo, era un jefe guerrero.

22 Tideo es un héroe procedente de Etolia y tampoco su historia se cruza con la de Heracles. Su mayor leyenda se resume en la lucha de los Siete Jefes contra Tebas. 


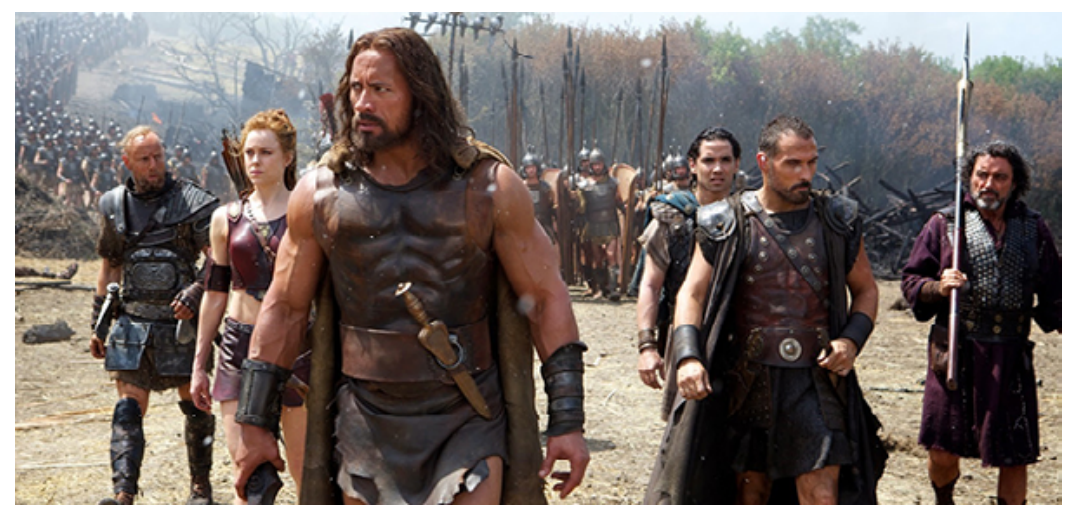

Fig. 26. Equipo de Hércules. De izquierda a derecha:

Tideo, Atalanta, Hércules, Yolao, Autólico y Anfiarao.

monsters are confined to the world of mere stories [...].By revealing Iolaus' story as fiction, Hercules programmatically sunders itself from conventional cinematic monomyth in favour of antiheroic «reality» ${ }^{23}$.

El film tiene pues como protagonista a un Hércules huérfano que intentó sobrevivir en Atenas y que encontró un lugar de refugio en el ejército. Su fuerza llamaba la atención y fue ganando fama haciendo creer en su procedencia divina y sus hazañas contra los monstruos del mito griego. De esta forma, la producción se centrará en su actividad como cazarrecompensas y su trabajo para el rey Cotis ${ }^{24}$ -quien más tarde le traicionará-, enfrentado con Reso ${ }^{25}$, un presunto rey rebelde.

A pesar de esta descontextualización del mito y de la insistencia en presentarnos a un Hércules muy humano, diferente al de las fuentes, existe en la película un vínculo entre los dos héroes: la muerte de Mégara y sus hijos. En este sentido, al Hércules del film se le acusa de haber matado a su familia y tiene constantes pesadillas con un acontecimiento que, a pesar de no recordarlo fielmente, está relacionado con su mujer, sus hijos y el perro Cerbero. En realidad, el film nos desvelará más tarde que este hecho ocurrió debido a que Euristeo - rey para el que nuestro héroe había trabajado anteriormente- drogó a Hércules y soltó a tres lobos que mataron a su familia sin que él pudiera evitarlo debido a su estado.

${ }^{23}$ Hércules va más allá y adopta el enfoque ateo de Troya, no solo manteniendo a las divinidades fuera de la pantalla, sino también ocultando toda la evidencia de su ser [...]. Al revelar la historia de Yolao como ficción, Hércules se desvía programáticamente de los monomitos cinematográficos convencionales en favor de la «realidad» antiheroica. Traducción de la autora.

${ }^{24}$ Cotis I fue un rey tracio de aproximadamente el siglo iv a.C. Su relación con Heracles es inexistente.

${ }^{25}$ Sin relación alguna con Heracles, Reso fue un héroe tracio que luchó con los troyanos en la guerra de Troya y alcanzó la muerte de mano de Ulises y Diomedes. 
Además de este posible nexo con las fuentes, al final del metraje Hércules tras ser capturado por Euristeo y Cotis -aliados-y atado a unas columnas -que romperá como lo hizo Sansón en el templo de los filisteos- se enfrentará a tres lobos que encarnan realmente a la figura de Cerbero. Aunque ciertamente en el film no se tome como tal y no se recree en absoluto lo expuesto en las fuentes escritas, este fue el último trabajo que realizó Heracles para Euristeo. En relación con él, Apolodoro (II, 5, 12) expone:

Como duodécimo trabajo se le ordenó traer del Hades a Cerbero. Este tenía tres cabezas de perro, cola de dragón y en el dorso cabezas de toda clase de serpientes. [...] Heracles cubierto con la coraza y con la piel del león, lo encontró a las puertas del Aqueronte, rodeó con sus brazos la cabeza de la bestia, y aunque lo mordió la serpiente de la cola no lo soltó, oprimiéndolo y ahogándolo, hasta que se hubo rendido [...] una vez mostrado el Cerbero a Euristeo, lo volvió al Hades.

\section{CONCLUSIONES}

En las páginas precedentes hemos realizado un estudio del modo en el que el séptimo arte producido durante el presente siglo ha asumido e interpretado la historia de uno de los más celebres hijos mortales de Zeus. Estos films, que se consideran herencia directa de los péplums italianos de los años 50 y 60 , y que se pueden encasillar dentro del neopéplum, muestran de manera general características propias y siguen, en cierta medida, el mismo esquema.

Uno de los aspectos principales y comunes a tres de las cuatro producciones estudiadas es el planteamiento de las mismas partiendo de la base del evemerismo. Esta teoría surgió en el siglo IV y defiende la visión de los dioses clásicos desde un punto de vista más lógico y racional. De este modo, el evemerismo explica que los dioses fueron en su origen humanos mortales que a causa de sus hazañas heroicas, su fuerza y su inteligencia, con el paso del tiempo fueron deificados y mitificados. Así, bajo este credo, se puede explicar que en Hercules (2005), a pesar de mantenerse vigente el conflicto entre divinidades, el héroe mitológico sea en realidad hijo del mortal Anteo. Tal como exponen Patricia Salzman y Jean Alvares (2018):

While we see centaurs, satyrs, and various monsters, the gods themselves never appear, and Hercules comes to realize that the excesses of Greek religion are human abominations, not divine commands. [...] As happens in several movies, this Hercules embraces the moral condition, helps end long-standing conflicts, and embraces a newer, more moral view of divinity ${ }^{26}$.

${ }^{26}$ Mientras vemos centauros, sátiros y monstruos variados, los dioses nunca aparecen en sí mismos, y Hércules llega a darse cuenta de que los excesos de la religión griega son abominaciones humanas, no órdenes divinas. [...] Como sucede en varias películas, este Hércules se acoge a la condición moral, ayuda a poner fin a conflictos de larga duración, y ampara una visión renovada y más moral sobre la divinidad. Traducción de la autora. 
Lo mismo ocurre con Hercules Reborn (2014) y Hercules (2014), en las que los dioses no aparecen, no hay rastro de seres mitológicos y, además, Hércules es concebido como un ser muy humanizado con problemas y miedos comunes como los que podría sufrir cualquier persona. Así mismo, que los films presenten la historia como una leyenda, además de que el propio héroe llegue a negar su procedencia divina, recalca y afianza la tendencia evemerista de estos films

The Legend of Hercules, por su parte, personifica a Hera mediante Alcmena y deja claro que es Zeus quien engendra al joven. Sin embargo, esto no significa que el film se aleje por completo de la idea del evemerismo ya que lo que esta postula hace que los dioses se representen mediante actividades humanas con una vida común: en este caso, la diosa empatiza con la mortal que se encuentra preocupada por la tiranía de su rey. Igualmente, también en este caso Alcides niega en un principio ser hijo de un dios.

Además de este aspecto, es curioso cómo se gestiona en estas cuatro películas la figura de Heracles. Si bien su enfoque es siempre tendente hacia la heroicidad sobrehumana del mismo, no se le presenta en ninguna de ellas como un verdadero semidiós, ni se muestra un posible contacto con el Olimpo. A excepción de la primera película analizada, ningún otro film hace alusión a la apoteosis y deificación de Heracles, tal y como se expone en las fuentes. La fidelidad a las fuentes de Hercules (2005), en relación con el resto de los films que trabajan la figura del héroe heleno en este siglo, la convierte en la única que hace referencia a la glorificación del protagonista. Aunque, evidentemente, no ocurre de la misma forma que en los textos, como ya hemos podido observar, la escena en la que Hércules se introduce en una pira ardiente y es salvado por la intervención de -presuntamente- Zeus produce un cambio en el carácter del personaje pudiéndose pues establecer un paralelismo con la apoteosis que nos exponen los mitógrafos y que le otorgó su inmortalidad.

A diferencia de esta, el resto de las producciones nada tienen que ver con este hecho y siquiera sugieren un posible fin del personaje. Este tipo de películas que están realizadas para el gran público conciben en realidad a Hércules como un héroe al estilo de los "comunes». Este hecho hace que no tenga cabida la muerte o derrota del héroe protagonista ya que el gran público no lo entendería ni aceptaría.

Los últimos tiempos han estado bañados, en cierto modo, de un culto a la imagen personal que ha afectado en todos los ámbitos sociales. El cine es uno de ellos y la figura de Hércules no queda al margen de esta tendencia. Es cierto que desde la antigüedad ya se le describía en los textos como un hombre dotado de notable musculatura y fuerza pero en el caso del cine, y concretamente de estos últimos films, parece que el nombre de Hércules sea exclusivamente sinónimo de un hombre forzudo y de tez morena como si se tratara de un culturista. Lo cierto es que, si algo tienen en común las cuatro películas, es que el protagonista se ciñe estrictamente a estos cánones estéticos y, a pesar de que el carácter que se refleja en los textos pueda quedar en duda, su físico se convierte en algo que no se puede separar del personaje.

Del mismo modo, la historia de Hércules bajo el filtro de un cine comercial ha provocado que en todos los films producidos en este siglo, la historia amorosa esté presente o sea el objetivo del héroe. En el caso de Hercules (2005) y The Legend of Hercules (2014) se hace obvio este hecho ya que la figura femenina como 
esposa o pareja -Deyanira y Hebe respectivamente- se convierte en fundamental para motivar y alentar al protagonista a sortear los obstáculos que se le presentan durante el metraje. Por su parte, en el caso de Hercules (2014) y Hercules Reborn (2014) el aspecto afectivo amoroso se muestra como un objetivo final. Aunque no directamente, los dos films reflejan a un Hércules que después de sus últimas hazañas -las que vemos en el film-y de superar el traumático asesinato inducido de su mujer y sus hijos, pretenden rehacer su vida con la pretensión de crear una familia bajo un nuevo «yo».

Finalmente, como hemos podido comprobar a lo largo de este estudio, cabe señalar que las palabras que dan título a este trabajo definen el uso que el séptimo arte de este siglo hace de los mitos del héroe griego, y en general de la mitología clásica, deformándolos y dándoles una nueva dimensión que los adapta al gusto y la realidad de las sociedades de nuestro tiempo. 


\section{BIBLIOGRAFÍA}

Alonso, Juan J., Mastache, Enrique A. y Alonso, J. (2015), La antigüedad en el cine. Egipto, Grecia y Roma. Madrid, T\&B Editores.

Apolodoro (2013), Biblioteca (Introducción de Javier Arce y traducción y notas de margarita Rodríguez de Sepúlveda). Madrid, Gredos.

Apolonio De Rodas (2011), Argonáuticas (Introducción y traducción de M. Valverde Sánchez). Madrid, Gredos.

Bonnefoy, Y. (dir.) (1997), Diccionario de las mitologías. Volumen III: de la Roma arcaica a los sincretismos tardios. Barcelona, Destino.

Curley, Dan (2018), The Hero in a Thousand Pieces: Antiheroes in Recent Epic Cinema, en Augoustakis, Antony y Raucci, Stacie (2018), Epic héroes on screen. Edinburgh University Press. Edimburgo, 173-190.

Diodoro de Sicilia (1995), Biblioteca Histórica. Libros I-II (Coord. Jesús Lens Tuero). Madrid, Ediciones Clásicas Madrid.

Esquilo, Sófocles, Eurípides (2004), Obras completas (coord. Emilio Crespo). Madrid, Cátedra.

Estrabón (2001), Geografía. Vol. III, Libros VIII-X. (Traducción y notas de García Ramón, J.L.; García Blanco, José y Meana, María José). Madrid, Gredos.

Giordano, Michelle (1998), Giganti buoni. Da Ercole a Piedon (e oltre) il mito dell'uomo forte nel cinema italiano. Roma, Gremese Editore.

Goméz Mesa, Luis (1978), La literatura española en el cine nacional, 1907-1977. Madrid, Filmoteca Nacional.

GonZales, A. (1990), La Fresque et l'Imposture. Le péplum: un genre cinématographique qui se débat entre Histoire et Imaginaire. Annales littéraires de l'Université de Besançon, 429, 133-160.

Grimal, Pierre (2001), Diccionario de mitología griega y romana. Barcelona, Paidós.

Hesíodo (2000), Obras y Fragmentos: Teogonía, Trabajos y días, Escudo, Fragmentos, Certamen (Traducción y notas de Aurelio Pérez Jiménez y Alfonso Martínez Díez). Madrid, Gredos.

Higino (2009), Fábulas (Introducción y traducción de Javier del Hoyo y José Miguel García Ruiz). Madrid, Gredos.

IzzI, M. (2000), Diccionario ilustrado de los monstruos: ángeles, diablos, ogros, dragones, sirenas y otras criaturas del imaginario. Palma de Mallorca, Olañeta.

Ovidio Nasón, P. (1988), Fastos (Introducción, traducción y notas por Bartolomé Segura Ramos). Madrid, Gredos.

Ovidio Nasón, P. (2015), Metamorfosis (Introducción y notas de Antonio Ramírez de Verger y traducción de Antonio Ramírez de Verger y Fernando Navarro Antolín). Madrid, Alianza Editorial.

Pausanias (2000), Descripción de Grecia: Ática y Élide. Libros I, V y VI (Introducción, traducción y notas de Camino Azcona García). Madrid, Alianza.

Píndaro (2008), Obra completa (Ed. Emilio Suarez de la Torre). Madrid, Cátedra.

Ramírez Guedes, E. (2017), Una aproximación a la guerra de Troya y sus fuentes preilíacas. Latente: revista de historia y estética del audiovisual, I5, I55-200.

Ruiz de Elvira, A. (1982), Mitología Clásica. Madrid, Gredos. 
Salzman-Mitchell, P. y Alvares, J. (2018), Classical Myth and Film in the New Millemium. New York, Oxford University Press.

Tito Livio (2006), Historia de Roma desde su fundación (Introducción por Ángel Sierra). Madrid, Gredos.

Virgilio (2010), Eneida (Introducción de José Luis Vidal y traducción de Javier de Echave-Sustaeta). Madrid, Gredos. 